\title{
Arc-parallel extrusion of the Timor sector of the Banda arc-continent collision
}

\author{
Brendan Duffy, ${ }^{1}$ Mark Quigley, ${ }^{1}$ Ron Harris, ${ }^{2}$ and Uwe Ring ${ }^{1,3}$ \\ Received 7 September 2012; revised 6 March 2013; accepted 9 April 2013; published 14 June 2013.
}

[1] Structural studies of synorogenic basins in Timor using field and remote sensing techniques provide new structural and geomorphic evidence for syn-collisional extension in the converging plate boundary zone between the Australian Plate and Banda Arc. Fault mapping and kinematic analysis at scales ranging from outcrop $\left(<1 \mathrm{~m}^{2}\right)$ to the dimensions of the active orogen in East Timor $\left(\sim 100 \mathrm{~km}^{2}\right)$ identify a predominance of NW-SE oriented dextral-normal faults and NE-SW oriented sinistral-normal faults that collectively bound large $\left(5-20 \mathrm{~km}^{2}\right)$ bedrock massifs throughout the island. These fault systems intersect at non-Andersonian conjugate angles of approximately $120^{\circ}$ and accommodate an estimated $20 \mathrm{~km}$ of NE-directed extension across the Timor orogen based on reconstructions of fault-dismembered massifs. Major orogen-parallel ENE-oriented faults on the northern and southern sides of Timor exhibit normal-sinistral and normal-dextral kinematics, respectively. The overall pattern of deformation is one of lateral crustal extrusion sub-parallel to the Banda Arc. Stratigraphic relationships suggest that extrusion began prior to $5.5 \mathrm{Ma}$, before pronounced rapid uplift of the orogen. We link this to progressive coupling of the fore-arc to an underthrust plateau on the Australian Plate and subduction of its ocean crust. Our results enable us to track the structural evolution of the upper crust during dramatic plate-boundary reorganizations accompanying the transition from subduction to collision. The deformation structures that we document suggest that both upper and lower plate deformation during incipient island arc-continent collision was largely controlled by the geometry and topography of the lower plate.

Citation: Duffy, B., M. Quigley, R. Harris, and U. Ring (2013), Arc-parallel extrusion of the Timor sector of the Banda arc-continent collision, Tectonics, 32, 641-660, doi:10.1002/tect.20048.

\section{Introduction}

[2] Quantifying the timescales and mechanisms by which an arc-continent collision develops from a subduction system is an important part of understanding the evolution of collisional orogens and the role of passive margin architecture in that process [e.g., Brown and Huang, 2009]. In principle, the process of arc-continent collision should result in contractional deformation as the ratio of subduction velocity to convergence velocity declines [e.g., Davis et al., 1983]. In practice, however, extension is reported from both ancient [Clift et al., 2004; Dewey, 2005] and modern arccontinent collisions [Gorney et al., 2007] including the island of Timor in the Banda Arc (Figure 1) [Price and

\footnotetext{
${ }^{1}$ Department of Geological Sciences, University of Canterbury, Christchurch, New Zealand.

${ }^{2}$ Department of Geological Sciences, Brigham Young University, Provo, Utah, USA.

${ }^{3}$ Department of Geological Sciences, Stockholm University, Stockholm, Sweden.

Corresponding author: B. Duffy, Department of Geological Sciences, University of Canterbury, 20 Kirkwood Ave, Ilam, Christchurch, Canterbury 8041, New Zealand. (brendan.duffy@clear.net.nz)

C2013. American Geophysical Union. All Rights Reserved. 0278-7407/13/10.1002/tect.20048
}

Audley-Charles, 1987; Harris and Wu, 1992; McCaffrey, 1996]. Young arc-continent collisions are commonly diachronous, and the concepts of space-time equivalence [Suppe, 1984] suggest that they should provide an important analogue for interpretation of features including extension in fossil arc-continent collisions. A wealth of models has been proposed elsewhere to account for extension of arc-continent collisions [e.g., Ave Lallemant and Guth, 1990; Harris, 1992; Cloos, 1993; Pubellier and Cobbold, 1996; Teng et al., 2000; Lister and Forster, 2009], but the collisional and extensional history of many of these orogens remains controversial and unresolved.

[3] The island of Timor lies in the outer arc region between the Timor Trough and the Banda Arc (Figure 1). It is the most mature part of the transition from subduction to collision of the Australian Plate with the Banda Arc and is the orogenic product of that collision [Carter et al., 1976; Hamilton, 1979]. The timing of the collision is controversial and estimates presently range from $\sim 3$ to $>8 \mathrm{Ma}$ [Keep and Haig, 2010; Audley-Charles, 2011]. Geophysical and field observations, along with shallow seismicity, show evidence of syn-collisional extension in Timor [Berry and Grady, 1981; Price and Audley-Charles, 1987; McCaffrey, 1988; 1989; Charlton, 1991; Charlton et al., 1991; Harris, 1991; Masson et al., 1991; Harris, 1992; Harris and Wu, 1992; Charlton, 1997; Keep et al., 2009; Keep and Haig, 2010] 


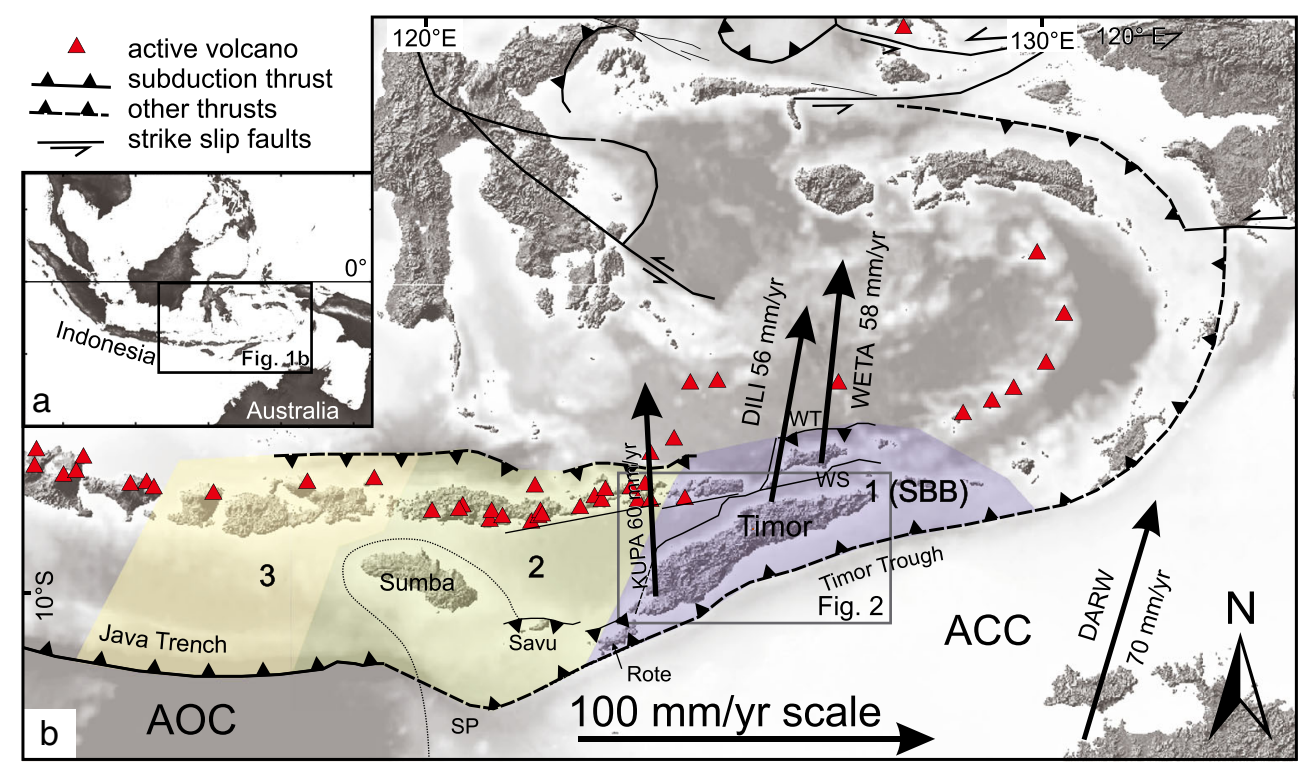

Figure 1. Tectonic setting of Timor and the Banda Arc. See inset for location. (a) Plate boundary elements. GPS plate motion vectors shown relative to the Sunda Shelf: WETA, Wetar (after Genrich et al., 1996); DARW, Darwin (after Nugroho et al., 2009). Coupling zones (after Nugroho et al., 2009) range from 1 (maximum coupling; South Banda Block-SBB) to 3 (minimum coupling; eastern Java Trench). WT, Wetar Thrust; WS, Wetar Suture; ACC, Australian continental crust; AOC, Australian ocean crust; and SP, Scott Plateau. Approximately $20 \mathrm{~mm}$ of differential movement occurs between Darwin and Wetar.

(Figure 2). The mechanism and effects of this extension are unclear. Small total displacements on the back-arc Wetar Thrust [Silver et al., 1983] do not constitute subduction polarity reversal [Snyder et al., 1996b], which has been inferred elsewhere to cause extension due to a reversal in basal shear stress [Pubellier and Cobbold, 1996]. Extension is commonly observed to be arc-parallel [McCaffrey, 1988; 1989; Masson et al., 1991]. This arc-parallel extension has been suggested to result from subduction zone advance and inundation [Harris, 1992], but most models that have been proposed imply arc-normal extension. The extension has been regarded as both superficial thin-skinned [Grady and Berry, 1977; Price and Audley-Charles, 1987] and basement-involved thick-skinned [Charlton, 1997]. Particular emphasis has been given to models that invoke slab rupture [Milsom and Audley-Charles, 1986; Price and Audley-Charles, 1987; Charlton, 1991; 1997; Sandiford, 2008] or delamination [Spakman and Hall, 2010], below Wetar. However, the short wavelength variability in regional uplift of Quaternary reefs is inconsistent with complete control by a deep uplift mechanism such as isostatic rebound and suggests that active faulting and/or folding must play a role in Timor's ongoing uplift [see Harris, 2011, p.199 and references therein].

[4] The previously unstudied extensional structures that cut synorogenic rocks in Timor Leste (the eastern half of Timor) offer a rare opportunity to track the structural evolution of the plate boundary zone that accompanied the initial transition from subduction to collision and to isolate the timing, kinematics, causes, and effects of extension. Previous tectonic models explaining Timor's extension have been based on limited field investigations. In this paper, we investigate the structural evolution of Timor Leste by mapping deformation in synorogenic sedimentary sequences.
We combine detailed outcrop investigations from three widely separated basins (Figure 2) with lineament analysis and re-interpretation of previous work. Our work identifies the kinematics, extent, and history of major extensional fault systems in Timor. Based on these data, an extrusion model is proposed for Pliocene to Recent regional extension that provides insight into the collisional geometry of Timor.

\section{Geological Setting and Previous Work}

\subsection{Geology of the Timor Sector of the Banda Arc}

[5] The Australian plate in the Timor region is moving NNE at rates of $\sim 70 \mathrm{~mm} / \mathrm{yr}$ relative to the Sunda Shelf, and its northern margin is being subducted under the greater Indonesian arc [Nugroho et al., 2009; DeMets et al., 2010] (Figure 1). Presently, the Australian continental slope collides with the Banda Arc and Fore Arc and drives it northward along the back-arc Wetar Thrust [Silver et al., 1983; Breen et al., 1989; Genrich et al., 1996; Snyder et al., 1996b]. The collision of the Australian continental slope in the Timor region gives way westward to subduction of the thinned Australian continental crust of the Scott Plateau below Sumba (dotted line Figure 1b) [Shulgin et al., 2009] and thence to subduction of Australian ocean crust below the Sunda Shelf at the Java Trench [Planert et al., 2010]. East from Sumba, the collision results in the development of a second, outer, non-volcanic arc of continental material in the fore-arc region, which includes Timor [Von Der Borch, 1979]. GPS campaigns show that the outer and inner arc islands of Timor, Wetar, and Alor (known collectively as the South Banda Block-SBB) are strongly coupled to Australia (Figure 1b). Ongoing contraction between Wetar and Darwin [Genrich et al., 1996; Bock et al., 2003; Nugroho et al., 2009] must be accommodated within the 

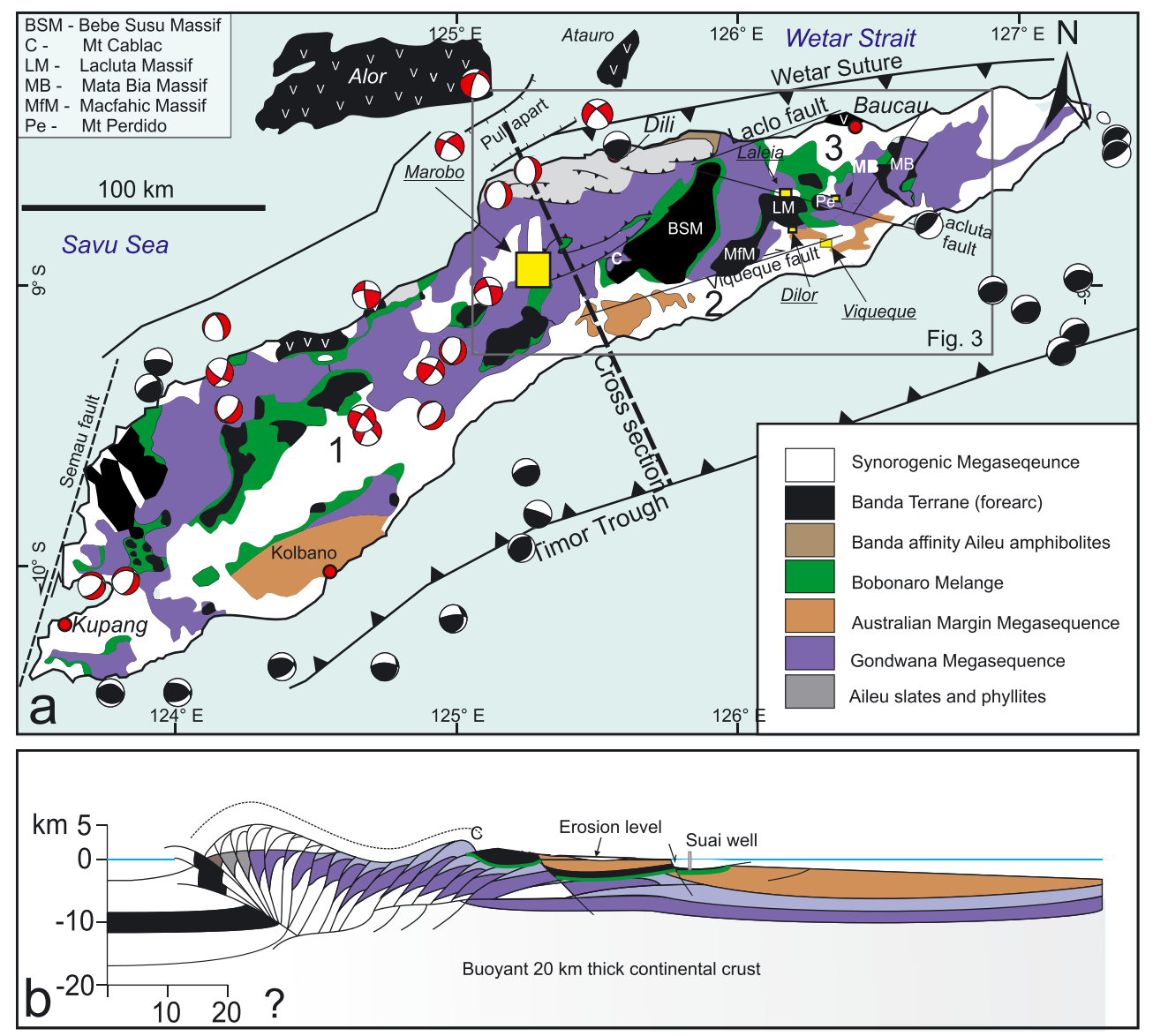

Figure 2. Generalized map and cross section of Timor. (a) Geological sketch map of Timor, modified after Harris et al. [1998] and showing terrane distribution. For location, see Figure 1. Three main synorogenic basins are the Central basin of West Timor (1) and the Southern (2) and NE basins (3) of Timor Leste. Yellow boxes show study areas (Marobo, Laleia, Dilor, Viqueque, Perdido from W-E). Seismicity at $<45 \mathrm{~km}$ depth is taken from the global Centroid Moment Tensor catalog (G. Ekström, A. Dziewonski, N. Maternovskaya, and M. Nettles, 2009, Global centroid moment tensor catalog,available at http://www.globalcmt.org/). Thrust solutions (black) are mostly confined to the deformation front south of Timor, while the remaining earthquakes are dominantly strike and normal slip (red). Pull apart basin west of Dili after Masson et al. [1991]. (b) Cross section through the highest topography of central Timor, adapted from Harris et al. [2000].

Timor orogenic wedge (Figure 2b). The coupling of Australia with the volcanic arc declines westward toward the subduction-collision transition [Nugroho et al., 2009]. The GPS segmentation correlates well with geochemical and isotopic segmentation of the arc [Wheller et al., 1987].

[6] Strike-slip and normal faulting is identified throughout the western Banda Orogen from its inception near Sumba [Breen et al., 1986] through the Savu Sea Basin [van der Werff, 1995] and in Timor [Charlton et al., 1991; Harris, 1991; Masson et al., 1991; Harris et al., 1998; Harris, 2011]. The western edge of Timor is bounded by a major discontinuity manifest in abrupt changes in bathymetry and topography, and truncation of well bedded sediments of the Savu Basin [Karig et al., 1987]. The discontinuity is also characterized by a linear zone of mud volcanoes [Barber et al., 1986; Harris et al., 1998]. Field mapping of Rote Island by Roosmawati and Harris [2009] recognized the discontinuity onshore and referred to it as the $123^{\circ}$ discontinuity. Kinematic indicators along the fault show mostly leftlateral strike-slip. However, a significant component of oblique slip is inferred due to the major change in topography across this structure [Harris et al., 2009].

\subsection{Tectonostratigraphy of Timor}

[7] The rocks of Timor are derived mainly from sedimentary cover sequences deposited on Australian continental crust [Charlton and Suharsono, 1990; Harris et al., 2000]. Permian to Jurassic rocks of the Gondwana Megasequence (Figure 2) fill intra-continental rift basins that formed along the northern margin of eastern Gondwana [Audley-Charles et al., 1988; Metcalfe, 1996]. Removal of the northern source region of the Gondwana Megasequence created the NW Australian passive margin, which is draped by post-rift sediments of the Australian Margin (or Kolbano) Megasequence [AudleyCharles et al., 1979; Charlton, 1989; Haig et al., 2007].

[8] A décollement presently propagates through weak shales overlying the breakup unconformity as Australian continental material arrives at the Timor trough (Figure 2b) [Karig et al., 1987; Breen et al., 1989]. Thrust earthquakes close to the décollement indicate that it remains active 
(Figure 2). The Gondwana Megasequence below the foreland part of the décollement, together with minor amounts of the Australian Margin Megasequence, is underthrust and incorporated into stacked duplexes that underlie the Banda Terrane fore-arc basement and dominate the outcrop of the northern three quarters of Timor [Harris, 1991; Harris et al., 2000] (Figure 2).

[9] An imbricate stack of Australian Margin Megasequence above the uppermost décollement is incorporated into the accretionary wedge [e.g., Harris, 1991; 2011] and exhumed on the south coast of Timor [e.g., Audley-Charles et al., 1979; Sawyer et al., 1993]. Onshore, the accreted Australian Margin Megasequence is separated from the Gondwana Megasequence by the Banda Terrane fore-arc basement, which extends south of Timor where it is penetrated by exploration wells [Audley-Charles, 1968; Charlton, 2002; Harris, 2011] (see Figure 2b). Weak shales below and within the décollement are highly overpressured and diapirically fed into the Bobonaro Mélange [Barber et al., 1986; Harris et al., 1998].

[10] The Aileu Metamorphic Complex on the north coast of Timor contains zircons and apatite with protolith ages of $>300 \mathrm{Ma}$ [Harris, 2006] and was exhumed from PT conditions that reached $9 \pm 1.2 \mathrm{kbars}$ and $826 \pm 37^{\circ} \mathrm{C}$ [Harris, 2011 , p.171]. It therefore represents synorogenically metamorphosed Australian continental basement and thus the northernmost extent of Australian continental crust [Berry and Grady, 1981; Berry and McDougall, 1986]. However, some of what is mapped as Aileu Complex may actually belong to the Banda Terrane [Ely, 2009].

\subsection{Shallow Seismicity of Timor}

[11] In West Timor, the few onshore earthquakes recorded are generally transtensional and include strike slip and normal earthquakes with $\mathrm{T}$ axes oriented E-W (Figure 2a) [McCaffrey, 1988; 1989]. Surface rupture during a $\mathrm{M}_{\mathrm{w}} 5.7$ strike-slip earthquake in westernmost Timor on 30 July 1975 shows evidence of both dextral and sinistral slip along vertical faults striking mostly NW-SE [Tjia, 1983]. Transtensional West Timor seismicity was interpreted by McCaffrey [1988, 1989] as indicative of dominant orogenparallel extension. A pull apart basin north of Timor appears to be created by eastward translation of Wetar relative to Alor [Masson et al., 1991] and has been the focus of normal faulting earthquakes [McCaffrey, 1988] (Figure 2). Nevertheless, offshore seismicity surrounding West Timor is generally contractional. Little onshore historical seismicity has been recorded in Timor Leste. Offshore, several thrust events occurred with $\mathrm{M}_{\mathrm{w}}>5$ on or close to the décollement at depths of $18-30 \mathrm{~km}$ below the northern flank of the Timor Trough (Figure 2a). Immediately north of the Timor Leste capital city of Dili, a thrust event was recorded at $\sim 30 \mathrm{~km}$, along with extensional earthquakes at $16-20 \mathrm{~km}$.

\subsection{Timing of Collision}

[12] Collision refers here to the first contact between the thinned Australian continental margin and the Banda Fore Arc. The timing and style of this event in Timor is debated [e.g., Audley-Charles, 2011], particularly since some authors renewed arguments for an old collision at $<8 \mathrm{Ma}$ [Haig and McCartain, 2007; Keep and Haig, 2010]. Keep and Haig's [2010] interpretation was based on biostratigraphy and on Berry and McDougall's [1986] $8 \mathrm{Ma}{ }^{40} \mathrm{Ar} /{ }^{39} \mathrm{Ar}$ ages for cooling of the synorogenic Aileu metamorphic complex. Those ages have been re-evaluated, and only a single white mica age was found reliable, which cooled to around $420^{\circ} \mathrm{C}$ at 5.4 Ma [Harris, 2011].

[13] The stratigraphic record of collision in the Kolbano area of West Timor (Figure 2) is bracketed by an unconformity between imbricated Early Pliocene carbonate rocks and undeformed Plio-Pleistocene equivalents [Audley-Charles et al., 1979; Sawyer et al., 1993; Charlton and Wall, 1994]. In Timor Leste, however, the bracket between $\sim 8 \mathrm{Ma}$ passive margin strata and unconformable $\sim 5 \mathrm{Ma}$ synorogenic strata is wider and does not lie within a single outcrop area [Haig and McCartain, 2007].

[14] Several authors have suggested that Wetar exhibits isotopic signatures of contamination by subducted continental material since $>4.7 \mathrm{Ma}$ [e.g., Herrington et al., 2011], but such interpretations are complicated by the need for assumptions about the composition of subducted sediment. Nevertheless, the extinction of volcanism on Wetar at $2.4 \mathrm{Ma}$ [Herrington et al., 2011] probably significantly post-dates collision, as is seen in the Aegean [Ring et al., 2010] and in West Timor and Sumba where the adjacent arc is still active even though collision initiated there at least 3 and $2 \mathrm{Ma}$, respectively [Harris, 2011].

\subsection{Synorogenic Geology of Timor}

[15] Timor is a doubly vergent contractional orogen [Harris, 1991; Richardson and Blundell, 1996]. The uplift of Timor has exhumed the Synorogenic Megasequence [Haig et al., 2007], which comprises mostly marine rocks that were deposited on the flanks of the Banda orogen. These rocks, which in Timor are generally found in contact with the Bobonaro mélange and unconformably overlying the other sequences (Figure 2), are distributed throughout the western Banda Orogen, from Sumba to Timor [Roosmawati and Harris, 2009]. In Timor, they are best exposed in the Central Basin of West Timor and the Southern and North East Basin of Timor Leste [Audley-Charles, 1968; Kenyon, 1974] (Figure 2).

[16] The base of the Synorogenic Megasequence is a late Miocene to early Pliocene chalky carbonate pelagite that grades up to a marl (the Batu Putih Formation) [Kenyon, 1974; R. W. Hopper, Nederlandsche Pacific Petroleum Maatschappij Preliminary Reconnoissance Report Netherlands Pacific Petroleum Company, unpublished report, 1942]. The Batu Putih Formation was deposited at depths of up to $2500 \mathrm{~m}$ since $5.5 \mathrm{Ma}$ [Haig, 2012]. The Batu Putih Formation in Timor is overlain by mid-Pliocene to early Pleistocene deep marine clastic sediments of the Viqueque Formation [Audley-Charles, 1968; Kenyon, 1974; Quigley et al., 2012]. Palynoflora from the type section of the Viqueque Formation records a two stage uplift of Timor that began $>4.5 \mathrm{Ma}$ and accelerated at $\sim 3 \mathrm{Ma}$ [Nguyen et al., 2013]. The Viqueque Formation in Timor Leste is overlain by shallow marine Pleistocene fan deltas, coral reefs, and fluvial gravels [Audley-Charles, 1968].

\subsection{Synorogenic Deformation}

[17] The Pleistocene coral reefs of Timor, Alor, and Wetar show evidence of rapid but variable uplift to elevations $>600 \mathrm{~m}$ on both sides of the $3000 \mathrm{~m}$ deep Wetar strait [see Harris, 2011, p.199 and references therein]. Despite this uplift and geophysical evidence for ongoing contraction, 


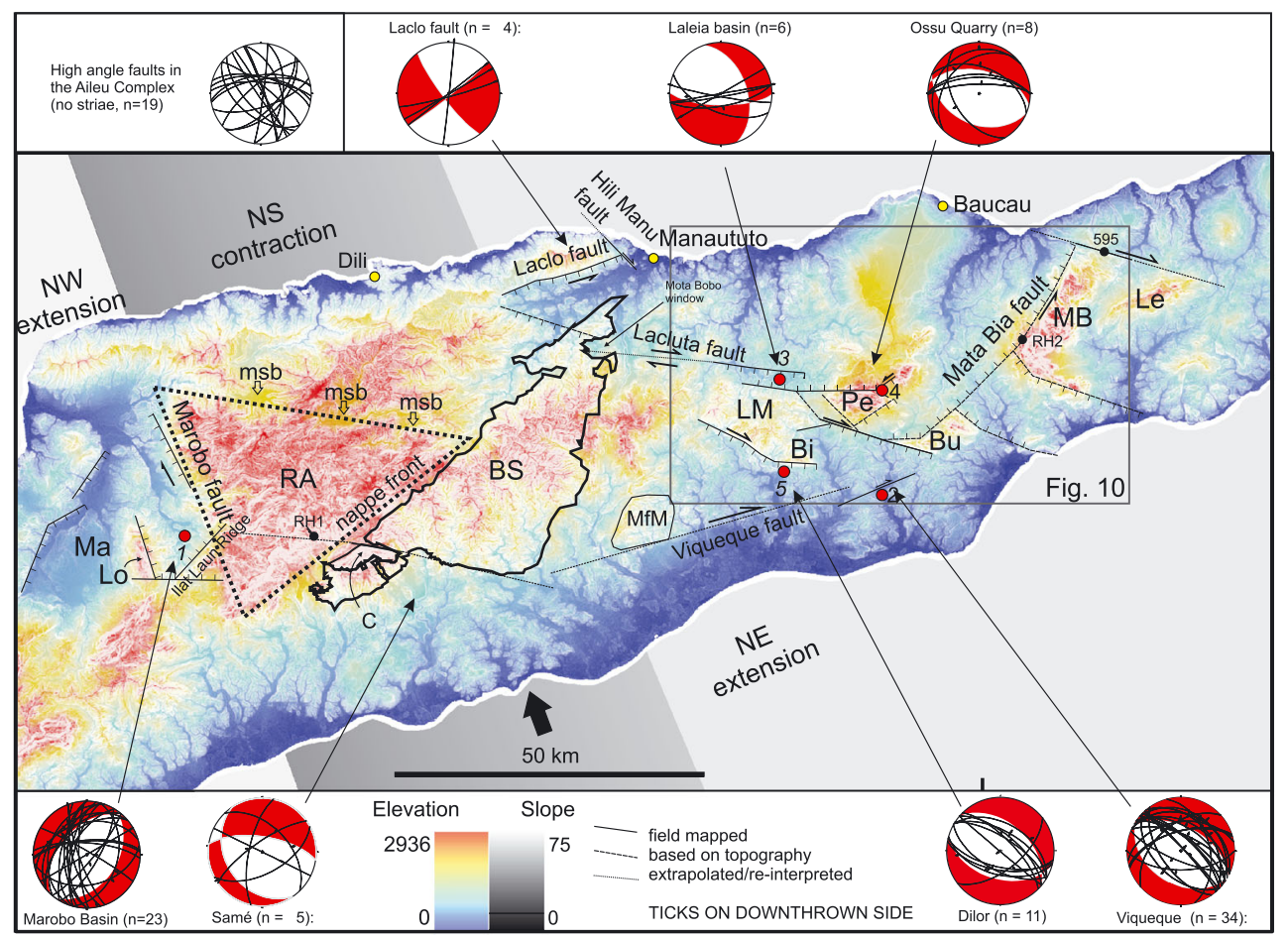

Figure 3. Combined SRTM elevation and slope map of Timor Leste, showing structural/geomorphic domains and lineaments regarded as the lateral continuations of major field-mapped transtensional faults. Hue represents elevation, and tone represents slope. For location, see Figure 2. Shortening direction is indicated by heavy black arrow. Locality numbers: 1, Marobo Basin; 2, Viqueque Basin; 3, Laleia Basin; 4, Perdido (MQ261); and 5, Dilor. Abbreviations: Bi, Mt Bibiliu; BS, Bebe Susu Massif; Bu, Mt Builo; C, Mt Cablac; Le, Legumau Massif; LM, Lacluta Massif; Lo, Mt Loelaco; Mat, Mata Bia Massif; msb, minor synorogenic basin; Pe, Mt Perdido; and RA, Ramelau Arch (within dotted triangle). Faults and striae are summarized from following figures.

the synorogenic sediments of Timor are mostly gently deformed. In the Central Basin of West Timor, some of the oldest synorogenic units are intensely shortened, whereas those preserved in Timor Leste are gently deformed by normal and strike-slip faulting [Audley-Charles, 1968; Kenyon, 1974]. In West Timor, much of the contraction has been attributed to diapir intrusion and mud volcanism localized along transtensional faults [Kenyon, 1974; Barber et al., 1986]. Major Pleistocene normal faults have been recognized in many parts of Timor, including the Kolbano region [Harris et al., 1998, Figure 3] within the Banda Terrane [Standley and Harris, 2009], the north sides of Mts Cablac and Perdido [Keep et al., 2009; Keep and Haig, 2010], and the sinistral normal Laclo fault [Berry and Grady, 1981; Harris, 2011]. However, the kinematics of this faulting is poorly understood.

\section{Methods}

[18] Detailed structural mapping was carried out around the town of Viqueque in central Timor Leste and followed by reconnaissance field mapping in the Laleia, Dilor, and Marobo basin areas, and the NE side of Mt Perdido (Figure 2). Field observations including the orientations of bedding and faults were mapped at 1:10,000 scale onto 2002 orthophotos and supplemented with stereoscopic analysis of 1950 s aerial photos. Fault plane striation data were collected wherever possible, together with observations of displacements and fault sense.

[19] The lateral continuity of mapped structures was investigated using an overlaid combination of elevation and slope maps derived from a 3 arc second (90 m) SRTM v4.1 DEM (Figure 3). This approach highlighted linear and curvilinear topographic lineaments that have been shown elsewhere to relate to crustal structure and zones of weakness, often reflected in the form of faults and fractures [e.g., Ganas et al., 2005].

\section{Synorogenic Structure, Kinematics, and Lineaments of Timor Leste}

[20] This paper divides Timor Leste into three structural geomorphic domains based on the dominance of distinct sets of structures (Figure 3).

\subsection{NW Extension Domain}

[21] The Marobo Basin of Central Timor (locality 1, Figure 3) lies immediately east of the Maliana Graben [Audley-Charles, 1968], which most authors regard as the easternmost limit of the $70 \mathrm{~km}$ long, orogen-parallel, synorogenic Central Basin graben of West Timor (Figure 2) [Brouwer, 1942; de Waard, 1956]. The Marobo Basin fill includes $>30 \mathrm{~m}$ of Batu Putih Formation carbonate pelagites overlain by $>700 \mathrm{~m}$ of Viqueque Formation clastic rocks 


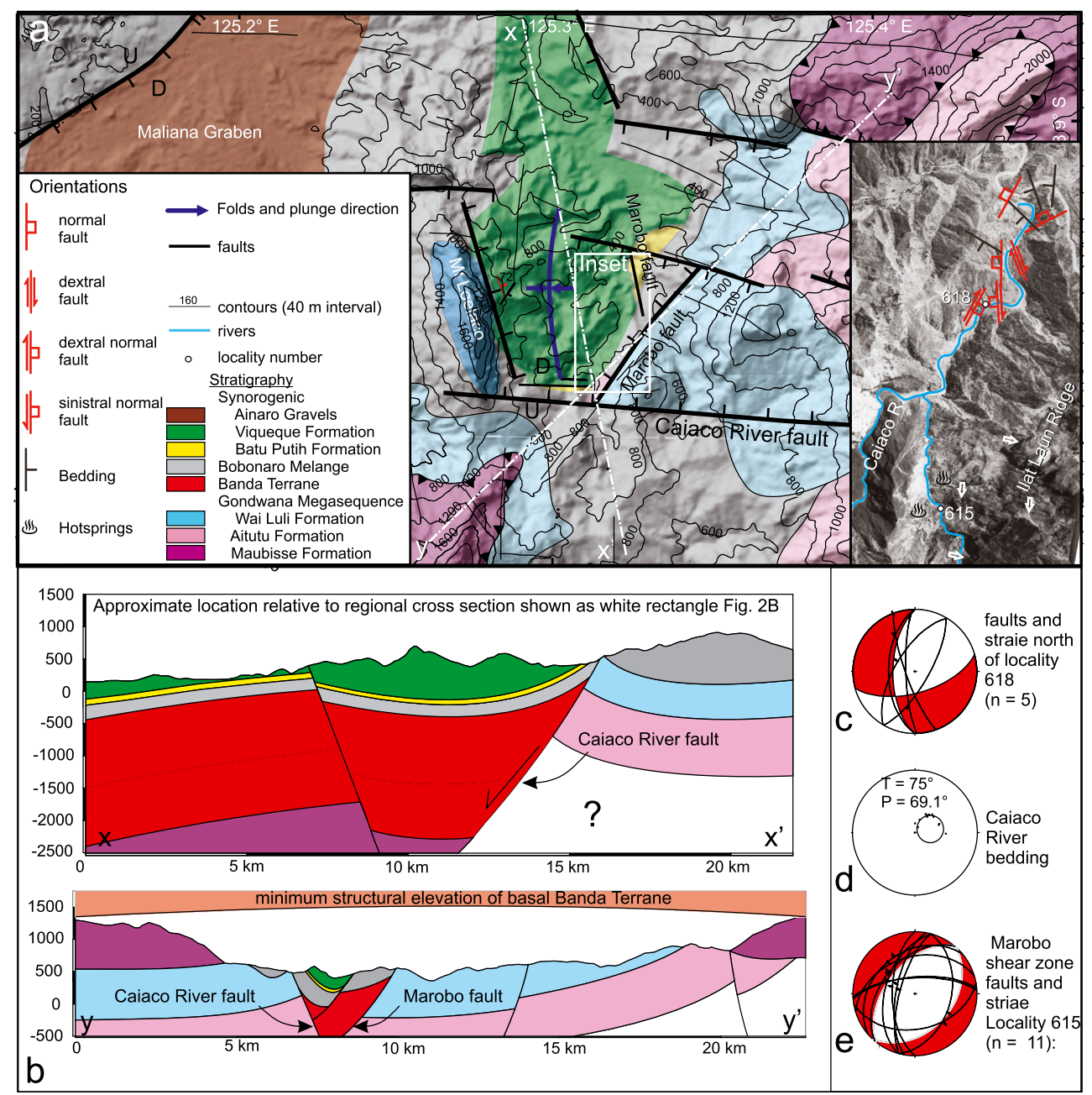

Figure 4. Geology of the Marobo basin. (a) Reconnoissance map of the Viqueque Formation in the Marobo basin. For location, see Figure 3. White rectangle shows area of investigation (see inset air photo); the remainder of the map is modified from Audley-Charles [1968]. Arrows on air photo indicate fault traces visible on 1950's air photos. (b) Cross sections drawn parallel to the syncline axis $\left(\mathrm{X}-\mathrm{X}^{\prime}\right)$ and parallel to the strike of the Aileu-Maubisse Nappe $\left(Y-Y^{\prime}\right)$. Estimation of the throw on the graben bounding faults depends on inferring a thickness for the Banda Terrane ( $>2 \mathrm{~km}$ ?) but is likely to exceed $4 \mathrm{~km}$. (c-e) Structural data from the Marobo Basin. For discussion, see text.

(Figure 4). The clastic sediments are composed dominantly of sericite schist lithics that Duffy [2013] found to be petrographically consistent with rocks reported from the Banda Terrane [Earle, 1980; Standley and Harris, 2009].

[22] The Marobo basin is fault-bounded to the west and east by rocks of the Gondwana Megasequence that crop out along Mt Loelaco and the Ilat Laun Ridge (Figure 4a and inset). Bedding within the Marobo basin strikes generally EW and defines a south-plunging syncline (Figures $4 \mathrm{a}$ and $4 \mathrm{~b})$. North-striking faults that cut the synorogenic rocks in the Caiaco River (north from locality 618 in Figure 4) have dextral oblique normal displacements and striae (Figure 4c), and bound well-preserved horsts and grabens in the active braided river bed, suggesting that they are recently active. Refolding of the basin sediments along the eastern boundary of the basin (Figure 4d) is consistent with approximately NS dextralnormal shear.

[23] In the south of the Marobo basin, a NE striking line of hot springs is created by meteoric waters that circulate deeply through active faults [Lawless et al., 2005]. A few tens of meters south of the hot springs, at locality 615 (inset, Figure 4a), a gorge in the Caiaco River exposes a $>50 \mathrm{~m}$ wide shear zone (Figure 5). The footwall rocks of the shear zone consist of Gondwanan Aitutu Formation limestones (Figure 5a) that have a pervasive S-C cataclastic fabric with $\mathrm{S}$ horizontal and $\mathrm{C}$ picked out by multiple brittle faults that show normal displacement. The normal faults in the Aitutu Formation strike approximately N-S and have dextral-normal slip. They are sub-parallel with and dip toward the Ilat Laun Ridge (Figure 4a). The hanging wall rocks at the northern (downstream) end of the shear zone consist of rocks of the Bobonaro Mélange. Like the footwall rocks, the hanging wall rocks of the shear zone exhibit S-C fabric at all scales (Figure $5 \mathrm{~b}$ and $5 \mathrm{c}$ ). The mélange is cut by two sets of oppositely dipping faults, one equivalent to those seen in the footwall and a second that has a more ENE/WSW orientation (Figure 4e).

[24] The net extension direction revealed by all faults is toward the NW (Figure 4e), but the rake rotates dependent 


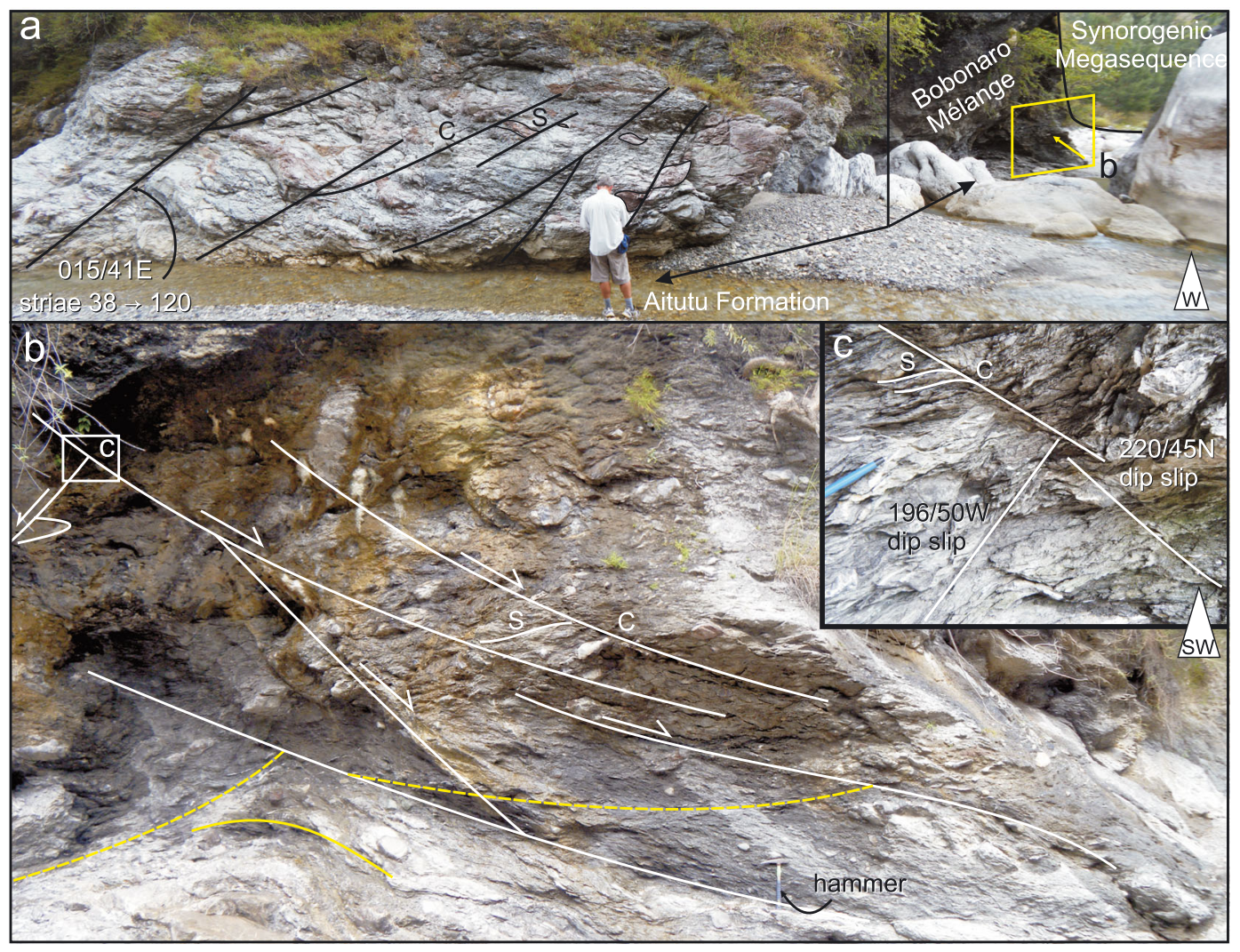

Figure 5. Structure of the Marobo shear zone, which provides good exposure of a fault with several km of high angle normal slip. (a) Extended Aitutu Formation, showing boudinage and S-C fabric development and high angle brittle faulting in the footwall of the shear zone. Faults strike $015^{\circ}$, parallel with and dipping east toward the Ilat Laun Ridge. (b) Shear zone in Bobonaro Mélange downstream (west) of the Aitutu Formation. White lines are normal faults, and yellow lines are boudinaged layers. This outcrop shows a strongly developed SC fabric at a range of scales (Figures $5 \mathrm{~b}$ and 5c).

on fault strike. EW-striking faults show a sinistral component of strike slip, and their orientation coincides with a $20 \mathrm{~m}$ high topographic scarp (the Caiaco River fault) that appears to truncate the southern end of Mt Loelaco (Figure 4). N-S faults show dextral oblique slip that parallels the strike of the basin-bounding Marobo fault, which defines the western edge of the Ramelau Arch of central Timor (Figure 3). The Marobo and Caiaco River faults accommodate differential NW-directed subsidence of the Marobo Graben relative to the Ramelau Arch.

[25] We estimate the minimum throw on the basinbounding faults using stratigraphic and structural relationships. The basal Batu Putih Formation was deposited at depths of around $2500 \mathrm{~m}$ [Haig, 2012]. It overlies an indeterminate thickness of the Bobonaro Mélange, which itself overlies Banda Terrane fore-arc rocks. The Marobo basin slowly shallowed but remained at depths $>1000 \mathrm{~m}$ [Haig, 2012], while the Banda Terrane east of the basin was uplifted to above sea level and began eroding into the basin. The Banda Terrane east of the basin is now mostly eroded away, and Gondwanan rocks of the underlying Maubisse and Aitutu Formations are exhumed to elevations higher than the synorogenic rocks in the basin (Figure 4b). This means that the Banda Terrane underlying the Marobo Basin is presently at a lower elevation than the base of the Maubisse nappe (Figure 4, section $\mathrm{Y}-\mathrm{Y}^{\prime}$ ). On this basis, the minimum displacement on the bounding normal faults is the sum of the thicknesses of the Maubisse nappe and Banda Terrane. The Maubisse Formation could be $>1 \mathrm{~km}$ thick [AudleyCharles, 1968]. The leading edge of the Banda Terrane fore-arc basement is wedge-shaped and thins southward, so its thickness is more difficult to estimate. However, it must have been thicker than $1.3 \mathrm{~km}$, the thickness of the Bebe Susu massif remnants of the Banda Terrane located SE of the Marobo Basin (Figure 3) [Audley-Charles, 1968; Standley and Harris, 2009]. The Banda Fore Arc west of Sumba is up to $9 \mathrm{~km}$ thick [Planert et al., 2010], and the Banda Terrane at least $2-3 \mathrm{~km}$ thick at the Mutis massif in West Timor [Harris, 2006]. The throw on the Marobo Basin-bounding faults may thus be several kilometers, which is consistent with the thickness of the Marobo shear zone and with the dramatic offset of the stack of thrust sheets exposed around the basin.

\subsection{N-S Contractional Domain of Central Timor}

[26] The Ramelau Arch of Gondwanan rocks dominates the high topography of Timor east of the Marobo Basin and is separated from the basin by the Marobo fault (Figure 3). The footwall of the Marobo fault exposes virtually flat lying Gondwanan Wai Luli Formation that thrusts southward in $\mathrm{km}$-scale exposures in the basin wall. These rocks form part of a thrust stack comprised of duplexes that were underplated 
below the Banda Forearc [Harris, 1991; Snyder et al., 1996a; Harris et al., 2000; Harris, 2011] and may have accommodated 50\% shortening [Richardson and Blundell, 1996] (Figure 2b). The stratigraphy within this stack youngs southward, which is consistent with upward ramping of the decollement in the underthrust continental margin units. Some out of sequence thrusts break through the duplex stack and its Banda Terrane roof thrust, emplacing Gondwanan rocks over the Banda Terrane at Mt Cablac (Figures 2a and 2b) [Keep et al., 2009].

[27] The Marobo fault forms the west side of the triangular-shaped Ramelau Arch (Figure 3), and the SE side of the arch is formed by thrust sheets. The NE side of the triangle is marked by a series of minor synorogenic basins (Figure 3), which lie on a NW-trending topographic discontinuity. NE of this line, the topography is lower than it is within the Ramelau Arch.

\subsection{NE Extension Domain}

[28] East of the Ramelau Arch in central Timor Leste, the high topography is dominated by isolated Banda Terrane klippe that include the Bebe Susu and Lacluta metamorphic massifs, and mixed-terrane massifs and mountains such as Mata Bia, Perdido, Builo, and Bibilu (Figures 2 and 3). We visited four areas in the NE extension domain that are strategically located relative to these massifs (localities 2-5, Figure 3).

\subsubsection{Contractional Structures}

[29] We report contractional structures here only from the Viqueque area, but they are widely mapped throughout the Southern basin by Audley-Charles [1968]. The Viqueque basin fill includes $>40 \mathrm{~m}$ of Batu Putih Formation carbonate rocks that locally thicken northward, overlain by $>200 \mathrm{~m}$ of Viqueque Formation clastic rocks that were emplaced southeastward [Duffy, 2013]. The succession is gently folded by $\mathrm{km}$-scale upright folds that trend NE-SW (Figures 6a-6c) [Audley-Charles, 1968; Duffy, 2013], approximately perpendicular to the regional shortening direction.

[30] The Viqueque anticline locally crossfolds the NEtrending structures (Figures 6a, 6d, and 6e). The structural dome at the intersection of the Cuha and Viqueque anticlines is cored by Bobonaro Mélange containing $<200 \mathrm{~m}$ exotic blocks. The north-dipping synorogenic strata on the northeast limb of the Viqueque anticline abruptly steepen into the northeast verging, locally overturned We Naekelek monocline (Figure 6a). The overhanging monocline is characteristic of shale diapirism, which is commonly associated with transtension in West Timor [Kenyon, 1974; Barber et al., 1986; Charlton et al., 1991; Harris et al., 1998] and in young synorogenic basins such as the Suai graben [Crostella and Powell, 1975, their Figure 10].

\subsubsection{WNW Striking Normal Faults}

\subsubsection{Viqueque Basin}

[31] The We Naekelek monocline is pervasively dissected by NW-striking faults. The faults are parallel to regional NW trending topographic scarps (Figure 3) and to the Viqueque anticline (Figure 6). Similar faults that are located immediately southeast and along axis of the Viqueque anticline (Figure 6) strike NW-SE, parallel to the Viqueque anticline and to the reach of the Cuha River in which they crop out. All of these faults have clear normal displacements, and striae are normal to slightly dextral (Figure 6f) The faults are pervasive but cannot be traced for more than a few tens of meters. Faults exposed at locality TS57 at the SE end of the type section take the form of a negative flower structure with dextral oblique normal faults bounding a central strike slip fault that parallels the type section reach of the Cuha River.

\subsubsection{Faults Bounding the Lacluta Massif}

[32] The Laleia Basin (Figure 7a; locality 3 on Figure 3) lies immediately north of the Lacluta massif rangebounding fault. The Batu Putih Formation is truncated at the rangefront and is overlain by thick cross-bedded conglomerates emplaced northward [Duffy, 2013]. This is in contrast to southward emplacement of sediments in the Viqueque area. The Lacluta fault between the Banda Terrane and the synorogenic basin is obscured; however, minor faults on both sides strike $280-290^{\circ}$, dip vertically to slightly north (Figure $7 \mathrm{~b}$ ), and have dextral to normal striae (Figure 7c).

[33] On the north side of the Laleia Basin, the synorogenic rocks dip southward and a thick package of gently dipping Batu Putih Formation occupies the highest topographic position (Figures $7 \mathrm{a}$ and $7 \mathrm{~b}$ ). South dipping oblique dextralnormal faults, with strikes of $258-290^{\circ}$ and gently westplunging striae, throw conglomerates of the Viqueque Formation on the hanging wall down against older Batu Putih Formation rocks (Figure 7b).

[34] In the context of the observed dextral and normal faults, we consider the Bere syncline to have developed over a basement pull apart graben that formed in a right-stepover between separate segments of the dextral Lacluta fault (Figure 7d). West of the Lacluta Massif, we show the Lacluta fault cutting across the northern end of the Bebe Susu Massif (Figure 3), which does not appear to be dextrally offset. However, the Banda Terrane of the Bebe Susu massif south of the Lacluta fault is $\sim 1 \mathrm{~km}$ thick, whereas north of the fault, only a very thin klippe of the basal Banda Terrane is preserved [Standley and Harris, 2009]. A fenster mapped on the east side of the klippen (Mota Bobo window; Figure 3) may be explained as the footwall to a SW dipping strand of the Lacluta fault that exhumes Gondwanan rocks underlying the base of the Banda Terrane. The lack of dextral displacement of the Bebe Susu Massif suggests that the dextral displacement declines westward.

[35] The synorogenic rocks are also down-faulted against the Lacluta massif on its southern side (locality 5, Figure 3) [Audley-Charles, 1968]. As seen in the Laleia basin, the range-bounding fault was not exposed but pervasive normal faulting cuts turbidites of the Synorogenic Megasequence close to the fault. The faults within the Synorogenic Megasequence strike parallel with Mt Bibiliu and striae reveal dextral oblique extension (see striae Figure 3).

\subsubsection{Mt Perdido}

[36] The south segment of the Lacluta fault in the Laleia basin breaks eastward into two strands that pass across the northern and southern faces of Mt Perdido (Figure $7 \mathrm{~d}$; locality 4 on Figure 3). The northern strand projects through a roadside quarry NE of Mt Perdido that is excavated in rocks of the Banda Terrane and Gondwana Megasequence (locality MQ261, Figure 8).We measured striae on several fault sets in the quarry, designated sets $\mathrm{C}$ to $\mathrm{E}$ (Figures $8 \mathrm{~b}-8 \mathrm{e}$ ). 


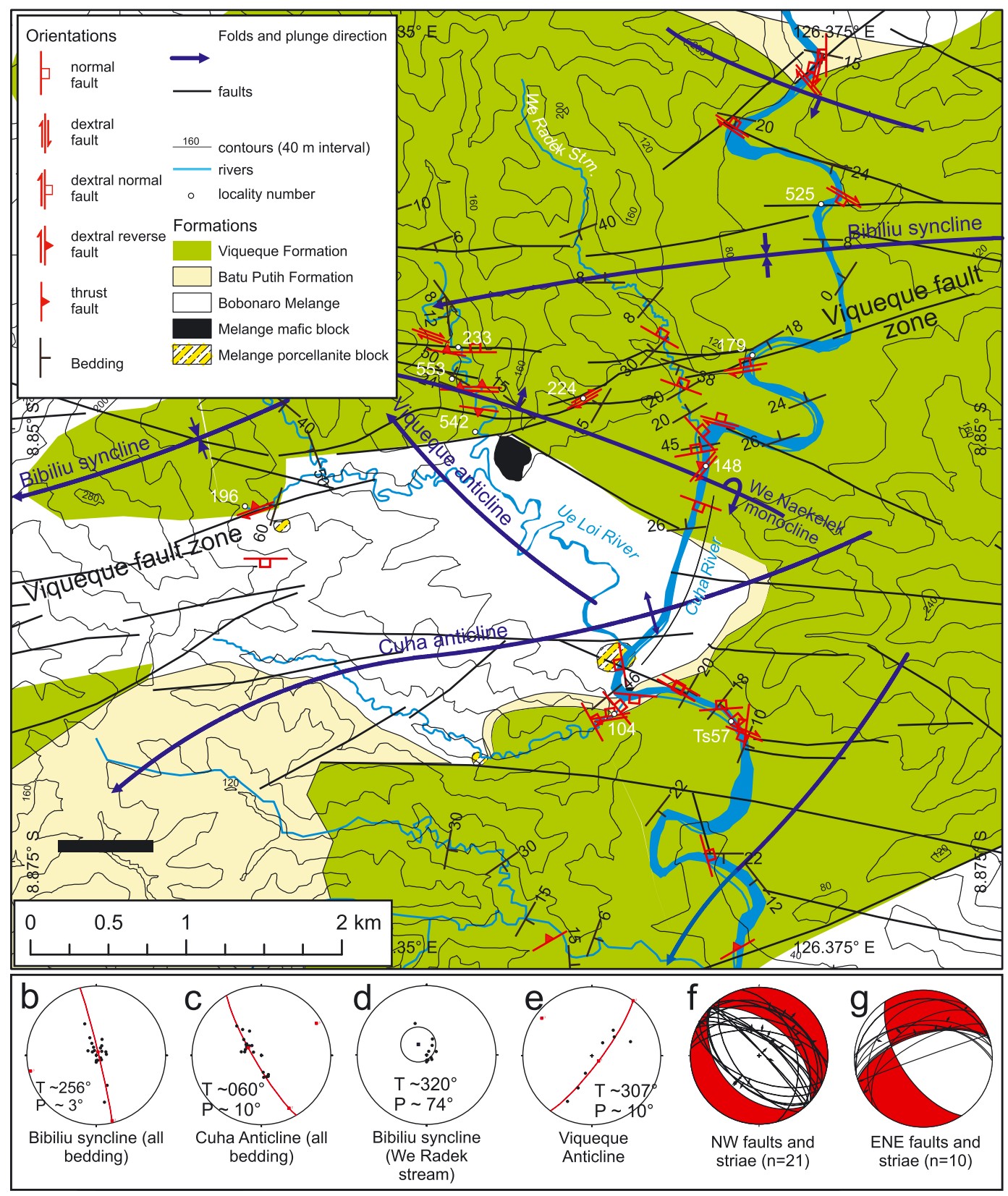

Figure 6. Structure of the Viqueque type area. (a) Geological map of the Viqueque area. Locality numbers shown white. (b-e) Bedding orientation data for various parts of structures within the Viqueque area. Note cross-folding of Bibiliu syncline in We Radek Stream by the Viqueque anticline. (f-g) Fault planes (lower hemisphere great circles), striations (arrows point in direction of motion of hanging wall), and average fault plane solutions (red) for NW striking (f) and NE striking faults (g) in the Viqueque area. For discussion, see text.

[37] Fault sets $\mathrm{C}$ and $\mathrm{D}$ (Figures $8 \mathrm{c}$ and $8 \mathrm{~d}$ ) are dominantly dextral oblique normal faults. Fault D (Figure 8d) juxtaposes structurally higher hanging wall rocks of the Banda Terrane against structurally lower Gondwana footwall rocks. This fault, which is clearly younger than the emplacement age of the Banda Terrane, has a welldeveloped thick gouge with cataclastic S-C fabric and a footwall breccia. Fault sets C and D parallel the scarps that form the northern boundary of Mt Perdido (set C) and the southern boundaries of Mts Perdido and Laritame (set D) (Figure 8a).
[38] Further faults at the quarry strike NE-SW and dip shallowly west. They have dextral-normal striae and crosscut the $\mathrm{E}-\mathrm{W}$ dextral-normal faults of set $\mathrm{C}$ (set E, Figure 8e). These faults strike parallel with the eastern boundary of $\mathrm{Mt}$ Perdido and the western boundary of Mt Laritame. The bounding faults of Mt Laritame can be seen from the quarry as steeply dipping linear scarps (Figure 8f).

[39] The fault kinematic data at the quarry indicate a pullapart relationship between Mounts Perdido and Laritame. The basement-involved extension at the quarry is consistent with data from synorogenic rocks elsewhere in this domain 

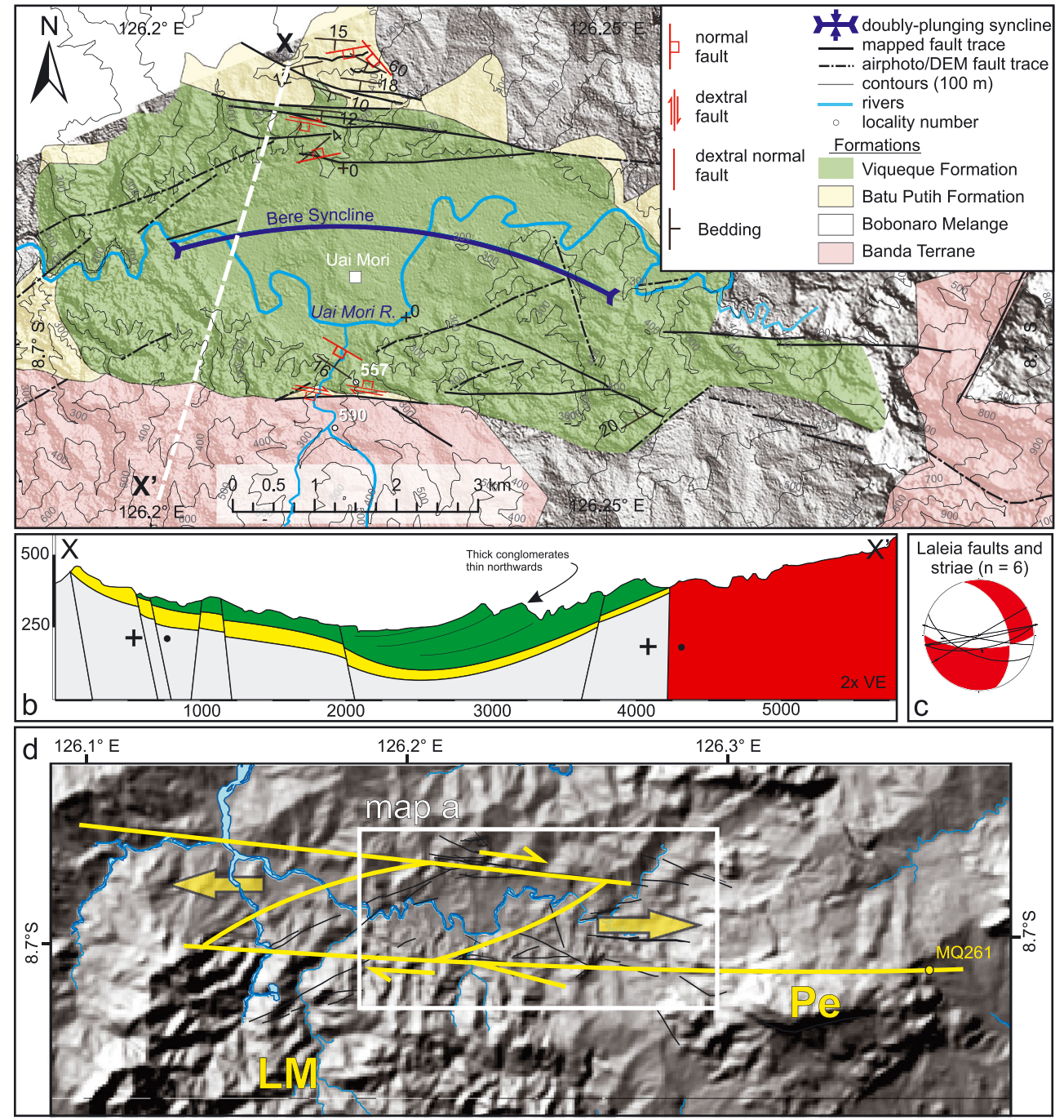

Figure 7. Reconnaissance geological map of the Laleia Basin. (a) Detailed structure showing distribution of lithologies. Note dextral faults on both sides of the basin. (b) Cross section showing forced folding of the Synorogenic Megasequence. (c) Faults and striae from the Laleia Basin. (d) Pull apart model for basin development, showing relationship to Mt Perdido and locality MQ261 (Figure 8).

(Figure 3). We interpret Mt Perdido as a horst block that is displaced from the Lacluta Massif along the dextral oblique normal faults that are exposed in the quarry and seen in the Laleia Basin. In contrast, Benincasa et al. [2012] recently interpreted Mt Perdido as a pop-up on an E-W sinistral fault system. Their hypothesis implies several kilometers of E-W sinistral offset to produce a pop up structure with the volume of Mt Perdido. None of our field data supports Benincasa et al.'s [2012] hypothesis.

\subsubsection{Other WNW Striking Structures Outside Synorogenic Basins}

[40] Approximately $50 \mathrm{~km} \mathrm{SW}$ of the Lacluta fault, Keep et al. [2009] documented a north-dipping high-angle normal fault (the Cablac fault) that drops the Banda Terrane of the Bebe Susu massif (BS Figure 3) down against Gondwanan rocks on the northern slopes of Mt Cablac (C on Figure 3). The Cablac fault forms a clear trace on airphotos that can be tracked eastward along the southern boundary of the Bebe Susu Massif and westward as a discontinuous series of en-echelon structures that extend as far west as the
Marobo graben (fine dotted line Figure 3). At locality RH1 (Figure 3), the fault trace truncates a sinistral normal fault that is oriented $137^{\circ} / 40 \mathrm{~S}$. Striae on the fault plane rake $55^{\circ}$ from the south (Figure 9a). This is consistent with its origin as an antithetic fault to dextral normal slip on the Cablac fault.

[41] Forty kilometers north of the Lacluta fault, the northern boundary of the Mata Bia Massif forms a continuation of the Baucau coastline to the west and parallels the Lacluta fault (Figure 3). E-W dextral fault strands with geomorphic offsets can be seen on aerial photographs north of Mata Bia (Figure 9b). Ground truthing at locality 595 in Figure 3 (Figure 9b) showed that the outcrop in the dextrally offset stream is brecciated and has horizontal striae.

\subsubsection{NE Striking Faults}

[42] NE striking faults define the western edges of the Lacluta massif, the Mata Bia massif, and Mt Builo. The western faces of Mata Bia and Builo occupy a single NE striking scarp (the Mata Bia fault) that parallels the extension direction observed in the NE extension domain (Figure 3). The 

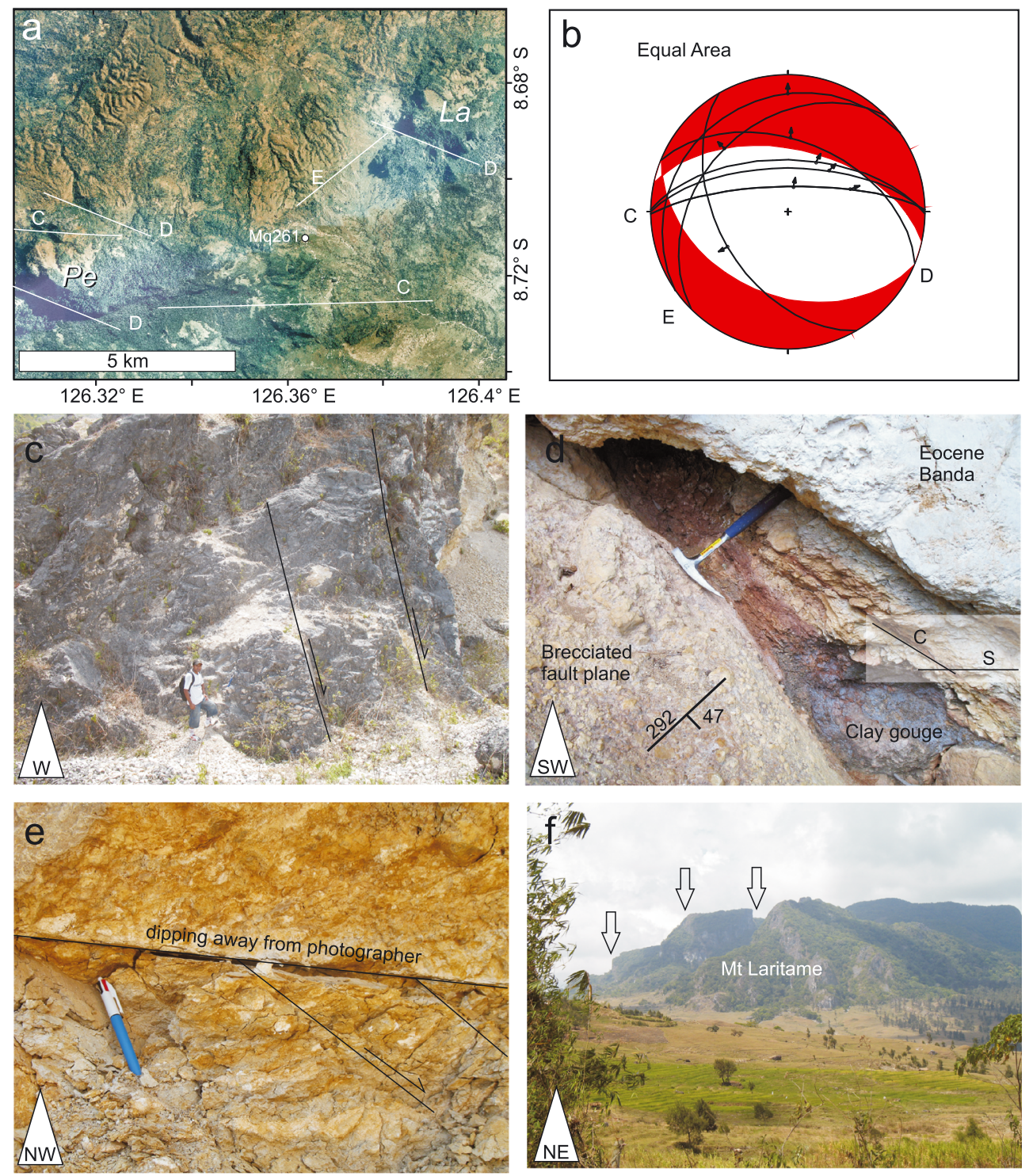

Figure 8. Quarry at locality Mq261 between Mts Perdido and Laritame in central Timor Leste. (a) Location of quarry and the orientation of distinct lineaments associated with the two mountains. Letter designations refer to sub-figures and also to the fault sets picked out in Figure 8b, the striae and fault plane orientation data collected at Mq261. (c-e) Examples of the various fault sets. For discussion, see text. (f) View NE from quarry to Mt Laritame showing steep scarps that define lineaments of fault set E.

current geological map for the region [Audley-Charles, 1968] shows that Gondwana Megasequence lies to the NW of the Mata Bia massif and that the Mata Bia massif is a klip of Banda Terrane sedimentary cover [Audley-Charles, 1968]. However, similar massifs of the Banda Terrane, including Mts Cablac, Perdido, and Laritame (Figure 3), have since been shown to be cored by exhumed Gondwanan rocks and surrounded by Banda Terrane [e.g., Haig et al., 2008; Keep et al., 2009; Keep and Haig, 2010; Benincasa et al., 2012].

[43] At locality RH2 (Figure 3), the Mata Bia fault has formed a thick breccia. The hanging wall rocks at the base of the scarp are red pebble conglomerate with volcanic clasts and fossils that belong to the base of the Banda Terrane cover sequence [Harris, 2006]. The footwall (east side) rocks are a massive, grey-weathering, cream-colored calcilutite with no obvious bedding or fossils, distinctly similar to Mesozoic
Gondwanan rocks reported from Mt Cablac [Keep et al., 2009, Table 1 ]. Stratigraphic revisions are yet to be published for the Mata Bia massif. However, based on reports outlined above from other massifs, and on observed structure, we infer a westward dip on the Mata Bia fault, which exhumes the Mata Bia massif as a large horst block of Australian-affinity rocks.

[44] Mata Bia and Builo are separated by a low-slope area that is bounded both north and south by scarps that parallel the orientation of the NW-SE faults (Figure 3). The Mata Bia fault is therefore inferred to have operated as a westdipping sinistral normal fault that accommodated northward translation of the Mata Bia massif away from Mt Builo. The "conjugate" angle between the NE sinistral normal and WNW dextral normal faults is $\sim 110^{\circ}$ rather than $60^{\circ}$ apart (Figure 3). 


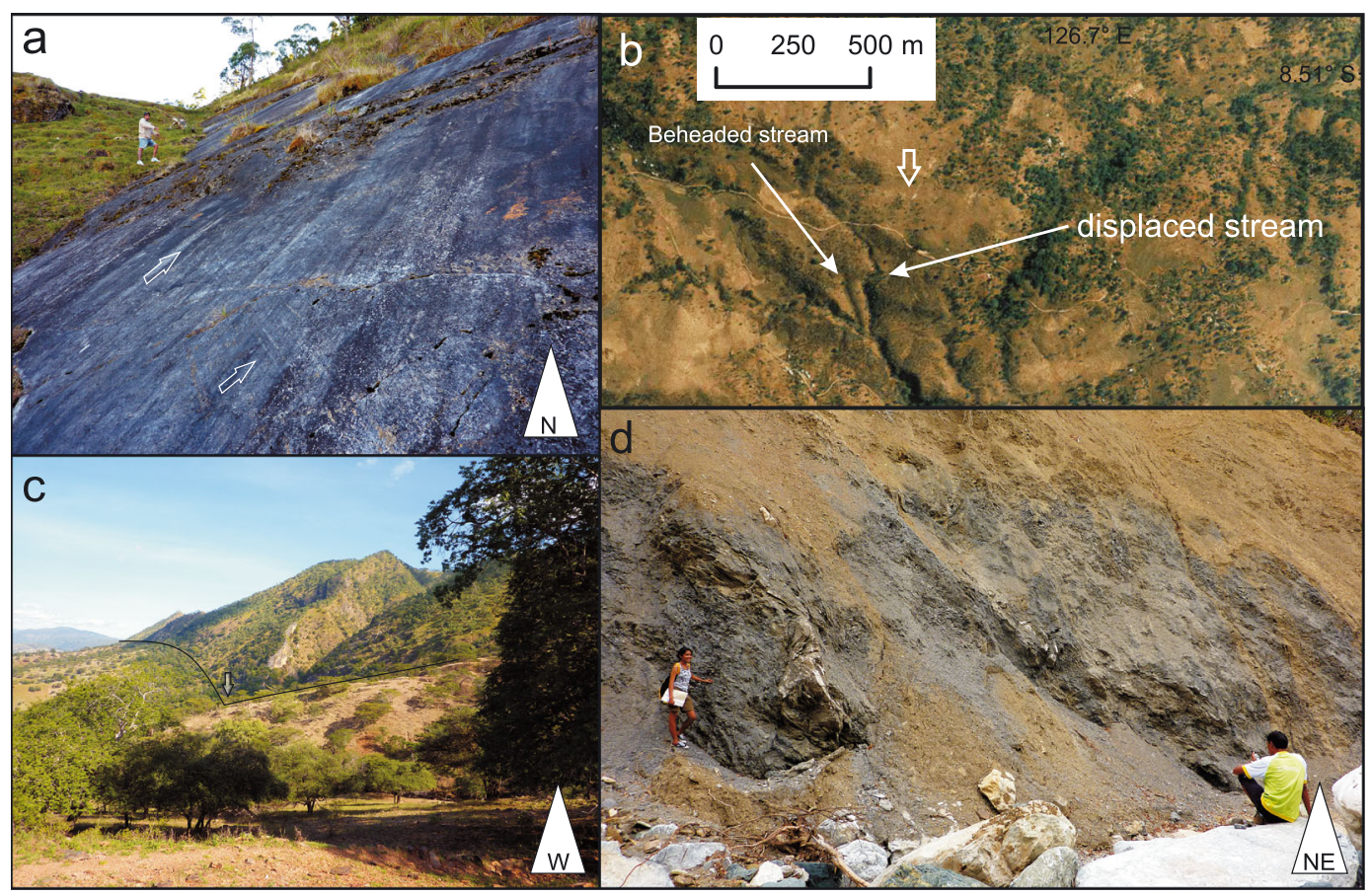

Figure 9. (a) Locality RH1 (Figure 3) showing striated fault plane on sinistral normal fault. (b) Locality 595 north of Mata Bia (Figure 3), showing example of dextrally displaced stream and nearby beheaded stream. Open arrow indicates probable parallel fault trace. (c) View west along the Laclo fault. (d) Thick gouge zone on the Laclo fault that strikes $075^{\circ}$ with various steep dips to the south. Sinistral oblique normal striae plunge $8^{\circ}$ toward $075^{\circ}$ (Figure 3 ).

\subsubsection{ENE Striking Faults}

[45] A series of fault outcrops at localities 179, 224, 542, and 196 (from east to west) expose an ENE striking (260 strike) fault system that passes through a series of left steps (the Viqueque fault zone; Figure 6). The outcrops are all dextral with shallowly plunging striae and a variable sense of dip slip. Just north of the Viqueque fault zone, at locality 233, intensely faulted rocks include outcrop of NW and ENE striking dextral normal faults. Localized contraction results from the interaction of these differently oriented dextral faults [e.g., Duffy et al., 2013]. The intersection of the ENE and NW striking faults makes an angle of $\sim 25^{\circ}$, a typical angle for Riedel shears.

[46] West of Viqueque, the dextral Viqueque fault zone can be traced as a topographic lineament that extends for more than $50 \mathrm{~km}$ along strike (Figure 3), at least to the SE corner of the Bebe Susu Massif. Striae measured along strike of the Viqueque fault zone at Samé (Figure 3) suggest that it may extend an indeterminate distance further to the SW. The Viqueque fault zone is truncated at its eastern end by the Lacluta fault (Figure 3), which is itself truncated at its western end by the normal [Berry and Grady, 1981], sinistral oblique [Harris, 2011] Laclo fault on the north side of Timor (Figures 3 and 9c and d). The Laclo fault, which exhumes the Aileu Metamorphic Complex in its footwall, parallels the Viqueque fault zone but striae indicate that it is of opposite sense (Figure 3).

[47] The Laclo fault is truncated at its NE end by an almost vertical faulted contact with the Hili Manu peridotite [Berry and Grady, 1981] (the Hili Manu fault; Figure 3) that strikes approximately $100^{\circ}$, parallel to the $100^{\circ}$ strike of the latest (extensional) deformation event in the Aileu Complex [Berry, 1981; Berry and Grady, 1981]. Shallow eastwardplunging striae on the fault, and its dextral offset of the Laclo River, are consistent with dextral offset as seen on similarly oriented faults in this study [c.f. Berry and Grady, 1981]. The mutual truncations of ENE and WNWstriking faults suggests that both sets are contemporaneous.

\subsubsection{Large Scale Fault dip}

[48] The massifs in the NE extension domain (Figure 10a) have steep, high western (Figure 10b) and southern boundaries (Figure 10c), with lower scarp elevations on their northern and eastern sides. This suggests that the major normal faults generally dip south or west, with footwall uplift to the north and east [e.g., Ganas et al., 2005]. Many of the profiles show evidence for north-dipping faults within the massifs that reduce the tilt created by footwall uplift (e.g., profile $\mathrm{H}-\mathrm{H}^{\prime}$, Figure 10c).

[49] An inferred southwest dip on the NW-SE faults is supported by the widespread exhumation of Gondwana rocks and the absence or poor preservation of clastic synorogenic rocks on the north side of the Lacluta fault (even the Laleia basin lies within the fault zone). Structurally high clastic synorogenic and Banda Terrane rocks are widespread on the hanging wall of the Lacluta fault.

\section{Discussion}

\subsection{Kinematics of Conjugate Strike Slip and Extension}

[50] Extension and strike slip faulting in the NE extension domain (Figure 3) occurs mostly on NE sinistral and WNW dextral oblique strike slip faults. These have a conjugate 


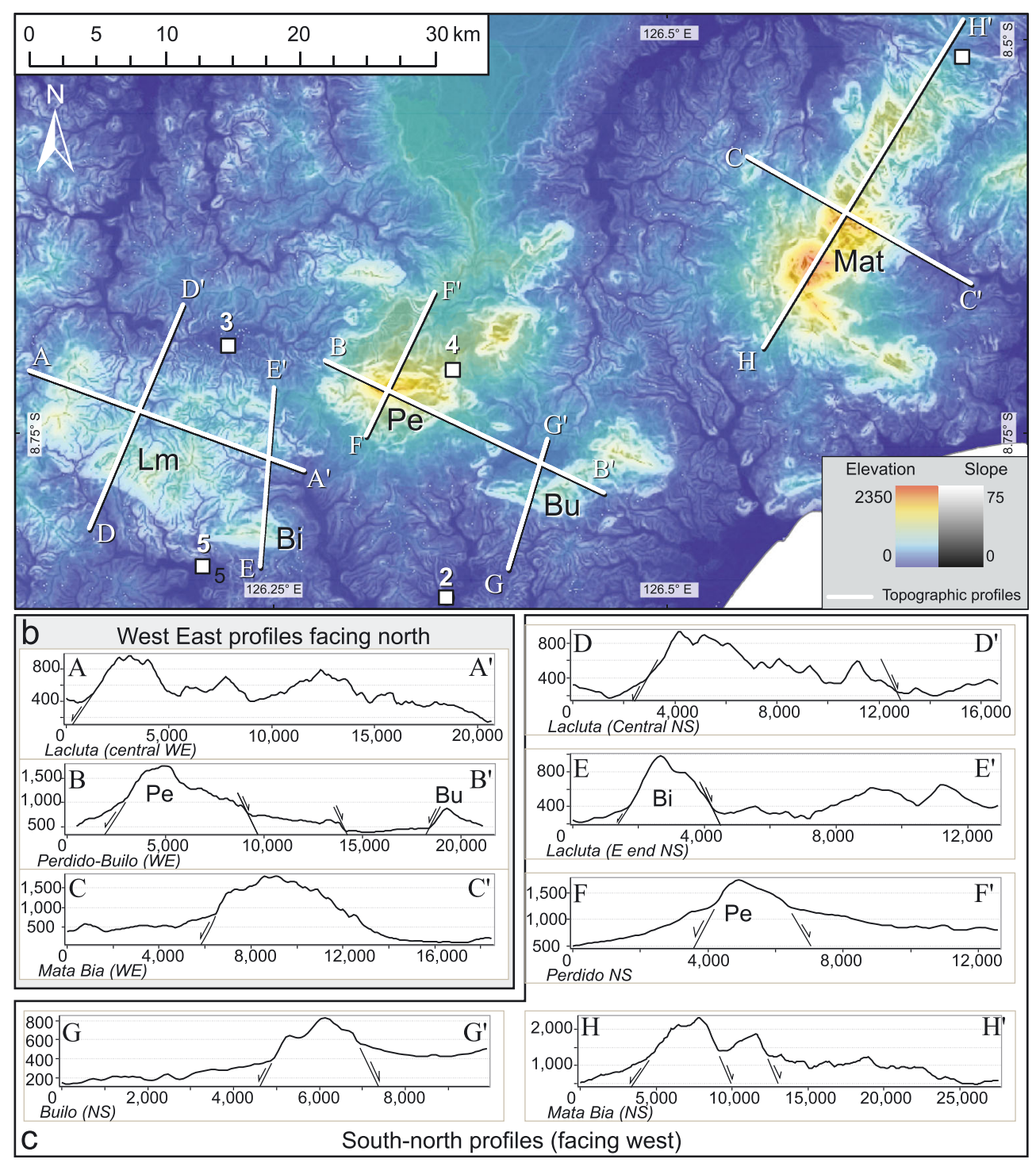

Figure 10. Scarp morphology of massifs of central Timor Leste. (a) SRTM combined slope and elevation map. For location, see Figure 3. Hue is indicative of elevation. Tone denotes slopes. Locality numbers: 2, Viqueque Basin; 3, Laleia Basin; 4, Perdido (MQ261); and 5, Dilor. Heavy black arrow shows extension direction of Viqueque normal faults. Bi, Mt Bibiliu; Bu, Mt Builo; Lm, Lacluta massif; Mat, Mata Bia massif; and Pe, Mt Perdido. (b) West east profiles of the massifs show that the steepest, highest NE-trending scarps are all located on the western faces and topography declines eastward, suggesting that the major normal faults are west-dipping. (c) North south profiles of the massifs show that all have their steepest scarps bounding their southern side, suggesting that the Viqueque and Dilor basins lie on the hanging wall of a major south-dipping fault system.

angle of $110^{\circ}$ and are mostly located between the ENE striking, opposing sense Laclo and Viqueque faults (Figure 11a). Structural observations within the fault-bounded massifs across Timor suggest that they have fold orientations that are consistent with each other and with the present stress regime [Standley and Harris, 2009]. This is inconsistent with vertical-axis block rotations during bookshelf-type strike-slip faulting and also precludes differential rotation of once optimally oriented antithetic faults during large scale strike slip tectonics. Subduction obliquity is also not responsible for arc-parallel extension in Timor [McCaffrey, 1996]. We therefore look for an explanation in similar fault geometries documented in other collisional orogens around the world including the European Alps, Tibet, and Mongolia [Ratschbacher et al., 1991; Taylor et al., 2003; Walker et al., 2008].

[51] Based on similarities between these orogens and Timor, we propose a paired general shear (PGS) model for Timor, based on the model of Yin and Taylor [2011]. In the PGS model, brittle surface extension is coupled to ductile extrusion at depth between opposite-sense shear zones, which are oriented perpendicular to the shortening direction (Figures $11 \mathrm{~b}$ and 11c). In Timor, these shear zones break to the surface as the Viqueque and Laclo strike slip fault zones (Figures 11a and 11b). Extrusion between these ENE striking fault zones is localized on their Riedel shears, which include 


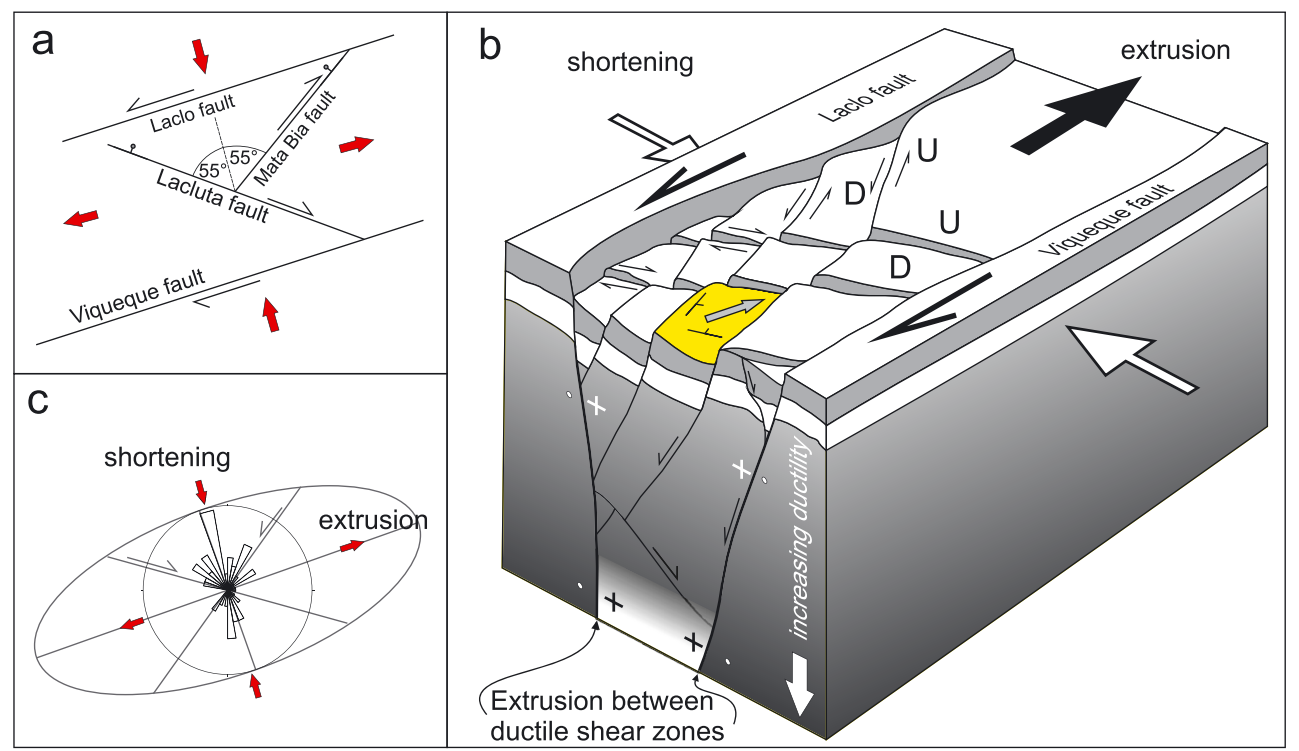

Figure 11. (a) Relationship between the orientations of cross-cutting Riedel shears and bounding opposite-sense strike slip faults in Timor. (b) Block diagram showing cross-cutting Riedel shears dipping toward the parent faults, creating a series of fault-bounded blocks that are tilted in the extrusion direction. The yellow highlighted surface shows how slip on the Riedel shears back-tilts the block in the extrusion direction. (c) Relationship between the shortening direction given by poles to bedding in Viqueque and the extrusion direction.

the Lacluta and Mata Bia faults. These Riedel shears must dip toward their master fault to join it at depth, which creates a series of fault-bounded blocks that are both tilted (e.g., Figure 10) and shuffled in the extrusion direction (Figure 11b).

\subsection{Reconstruction of a Dismembered Massif}

[52] Restoration of transtensional deformation is problematic because a great deal of movement occurs out of plane. However, we present a preliminary restoration of Timor Leste, based on the assumption that the topography of eastern Timor Leste expresses the arc-parallel extrusion of the island [e.g., Frisch et al., 1998 in the European Alps]. We collapse the displacement on the various major structures, beginning with the modern configuration (Figure 12a). A block including Perdido, Mata Bia, and Builo is translated west along the Lacluta fault to restore Perdido against the Lacluta Massif (Figure 12b). The gap between Builo and Perdido is then collapsed, also along the Lacluta fault, making Builo part of the Lacluta Massif (Figure 12c). Finally, the gap between Mata Bia and Builo is collapsed along the Mata Bia fault (Figure 12d).

[53] This restoration accounts for $\sim 20 \mathrm{~km}$ of extrusion and reconstructs a greater Banda Massif. Dextral striae on high angle EW normal faults at Mt Perdido (Figure 8) suggest that the Mata Bia Massif may restore further west across the north side of Perdido, parallel to the Lacluta fault (Figure 12d). This would increase the total extrusion recorded in the dispersal of the Banda Massif to $30 \mathrm{~km}$ but would also require westward restoration of the Baucau plateau, for which no field evidence presently exists. However, if the Hili Manu fault is involved, this restoration would collapse the western edge of Manaututo Bay. In support of this speculation, the restoration already partially collapses the distinctly telescopic linear elements of the Timor coastline. If these elements are structurally controlled, the extrusion may account for as much as $50 \%$ of the land area of Timor Leste.

\subsection{Timing of Extrusion}

[54] Components of an orogenic wedge may collapse repeatedly during its evolution, but clues to early events may be found in space-time equivalence along strike. For instance, the accretionary wedge between Sumba and Savu has collapsed, yielding a $4^{\circ}$ reduction in wedge taper [Harris, 1991]. This occurs at an early collisional stage due to an increase in fluid overpressure and simultaneous lowering of the coefficient of friction when the mud rich distal edge of Australia arrives at the trench [e.g., Mourgues and Cobbold, 2006]. In those parts of the wedge where collision is advanced, and mud volcanism and diapirism have dewatered the base of the wedge (e.g., Timor Leste), the taper is once again increased [e.g., Calassou et al., 1993].

[55] The extensional episode that we document here is also an early feature of collision but is distinct from wedge collapse and happens mostly in the hinterland of the wedge (Timor). Structural relationships in the Marobo basin provide an estimate of the age of inception of normal faulting in the NW extension domain. The Batu Putih Formation there records pelagic deposition in a deep basin, at $2500 \mathrm{~m}$ to $1000 \mathrm{~m}$ depth, beginning around 5.5 Ma [Haig, 2012]. Meanwhile, the Timor forearc overlying the adjacent Ramelau arch was being uplifted from below the Batu Putih Formation to above sea level. Timor Leste seems to have emerged by $\sim 4.5 \mathrm{Ma}$, and uplift accelerated at $\sim 3 \mathrm{Ma}$ [Nguyen et al., 2013], possibly due to the arrival of the Australian continental slope at the subduction trench [Bowin et al., 1980]. By $3.5 \mathrm{Ma}$, the accretionary wedge 
DUFFY ET AL.: ARC-PARALLEL EXTRUSION OF TIMOR

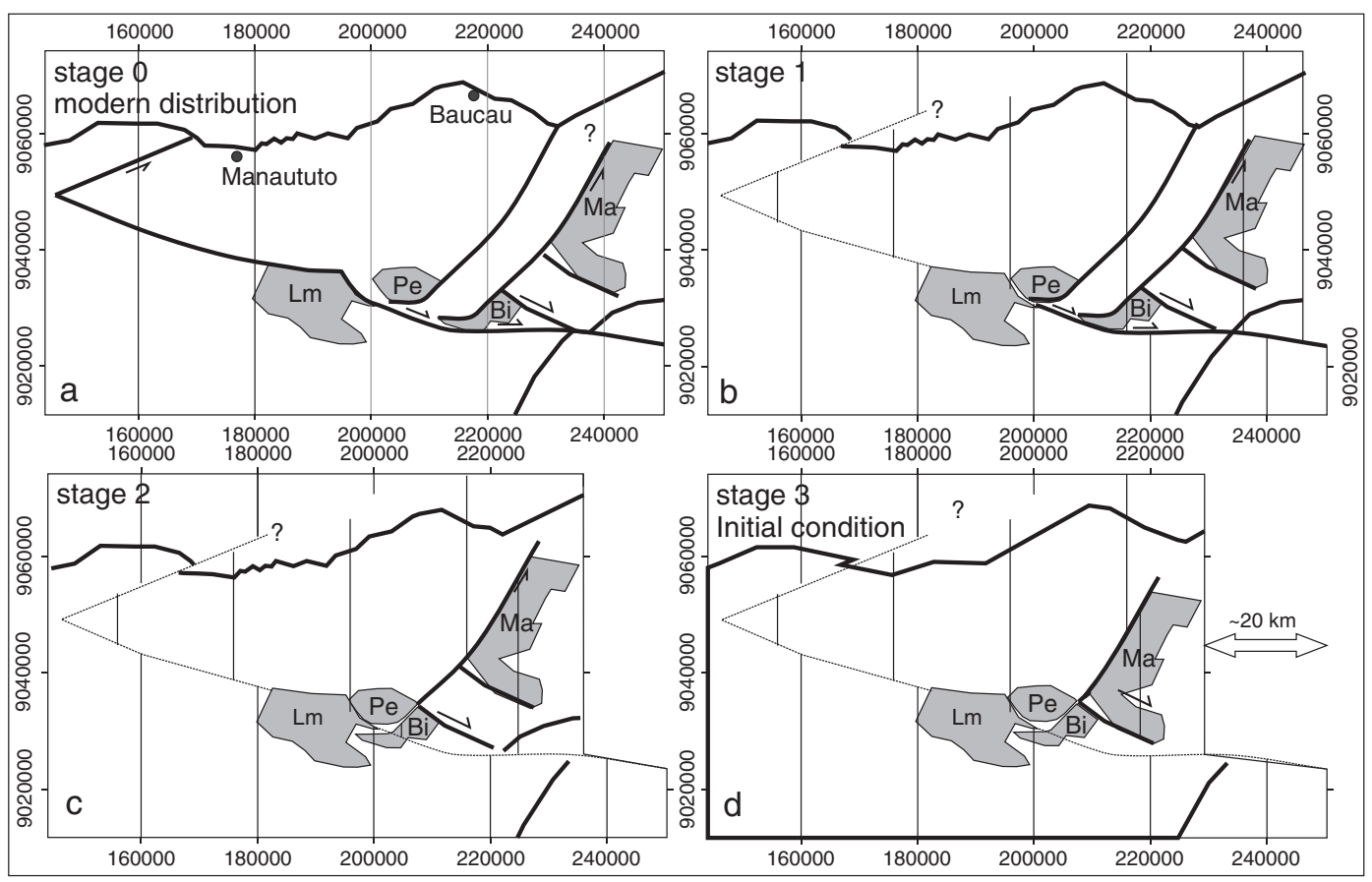

Figure 12. Three stage palinspastic reconstruction of central Timor Leste showing accumulation of at least $20 \mathrm{~km}$ of extension through fault separation only of the major fault blocks identified in this study. Graticules (WGS84, UTM52S) are in meters rather than degrees to best illustrate distance. The stages do not imply slip timing, which is presently unresolved, although section 5.3 indicates that extrusion began $<4$ Ma.

had been removed and fore-arc basement detritus was being deposited in the Marobo graben from the direction of the Ramelau arch [Duffy, 2013; D. Van Hinsbergen and B. Duffy, 2013 unpublished data]. Subsidence of the Marobo basin was therefore syn-collisional rather than postcollisional and preceded the arrival of the continental slope. Since the onset of deep marine clastic sedimentation post 3.3 Ma, the pelagic basin sediments have been uplifted to $400 \mathrm{~m}$ above sea level but the graben remains active, indicating that regional uplift exceeds local subsidence.

[56] In the NE extensional domain, the Laclo fault has exhumed the Aileu Metamorphic Complex [Berry and Grady, 1981]. White mica ${ }^{40} \mathrm{Ar} /{ }^{39} \mathrm{Ar}$ age determinations show that the Aileu Metamorphic Complex only cooled to around $420^{\circ} \mathrm{C}$ at $5.4 \mathrm{Ma}$ [Berry and McDougall, 1986; Harris, 2011]. Apatite fission tracks further show that the same rocks were rapidly exhumed from the partial annealing zone $\left(80-120^{\circ} \mathrm{C}\right)$ at rates of $<3 \mathrm{~mm} / \mathrm{yr}$ over $<4 \mathrm{~m}$.y. [Harris et al., 2000]. Taken together, these data indicate the inception of rapid extrusion in the NE domain since $\sim 4 \mathrm{Ma}$. This is the same age that extrusion was inferred from other data and arguments associated with a plane strain reconstruction of the orogen [Harris, 1992, Figure 3].

\subsection{Comparisons With Geodetically and Seismologically Inferred Deformation}

[57] Sparse regional GPS data show that the volcanic arc within the South Banda Block is strongly coupled to the Australian plate [Genrich et al., 1996; Bock et al., 2003; Nugroho et al., 2009] (Figure 1b) and that the coupling decreases systematically westward [Nugroho et al., 2009]. The GPS segmentation correlates well with geochemical and isotopic segmentation of the arc, which has been largely attributed to variations in the contribution of lower mantle material [Wheller et al., 1987]. This component must be passing through discontinuities in the lower plate. The geochemical/GPS correlation thus suggests that the structure of the lower plate exerts a fundamental control on the kinematics of the collision, or vice versa. The decrease in coupling of the upper and lower plates is reflected in global GPS velocities of islands within the Banda Arc (Figure 13), which are parallel to the arc and increase eastward, revealing an arc-parallel extensional regime. Bock et al. [2003] showed that the strain rate increases westward to a peak near the subduction-collision transition (Figure 13). If the decade of data represented by the GPS measurements can be extrapolated, then coupling changes appear to extend the arc, as has been previously inferred in the Caribbean [Gorney et al., 2007] and in keeping with our kinematic data.

[58] McCaffrey [1988; 1989] suggests that shortening of the upper crust in Timor during the last 40 years of instrumental earthquake data is accommodated by slip on transtensional faults. Our slip data, particularly from the NW extension domain, is consistent with most instrumental seismicity in the hinterland part of the collision in West Timor (red solutions in Figure 13). This suggests that the Marobo basin is an active graben, which is borne out by young scarp development in the modern bed of the Caiaco River.

\subsection{Pliocene to Recent Geodynamic Evolution of Timor}

[59] The extrusion we have mapped in Timor (Figure 14a), particularly in the NE extension domain, is similar to structures developed in response to indentor tectonics, at all scales from physical modeling [Dominguez et al., 1998; Boutelier et al., 2012] to collisional orogenesis [Ratschbacher et al., 1991; Taylor et al., 2003]. Analogous structures in the 


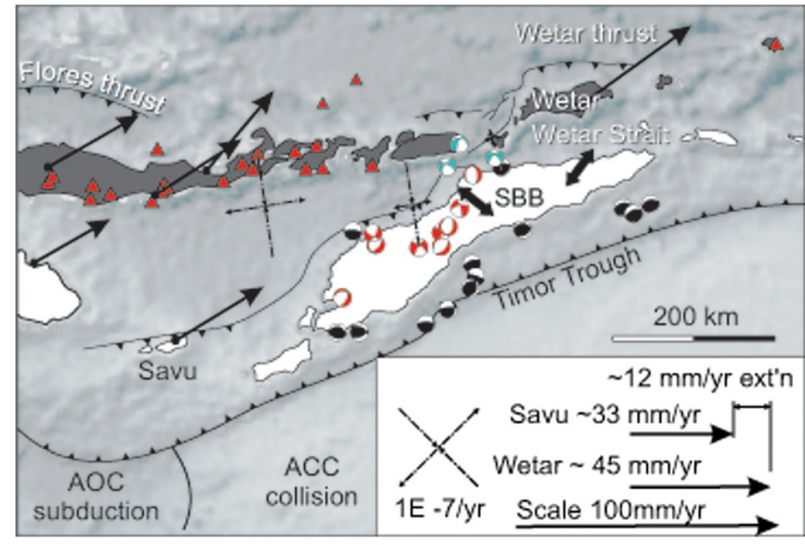

Figure 13. Summary of global GPS and seismicity data for the Timor region arc and fore arc. Heavy black arrows show global GPS velocities relative to ITRF 2000 [Nugroho et al., 2009], which increase eastward due to coupling. Fine dotted arrows show extensional strain fields developed by Bock et al. [2003], which increase westward. CMT solutions are shown for comparison with average extension direction from fault slip data (heavy double ended black arrows).

Eastern Alps lie on the foreland side of the Adriatic indentor and result from extrusion off the flanks of the indentor [Ratschbacher et al., 1991] (Figure 14b). Tibetan extrusion results from the indentation of India into Eurasia [Molnar and Tapponnier, 1975]. In both the Alps and Tibet, the extrusion is late-collisional and aided by a weak middle/lower crust and the unconfined eastern boundaries of both orogens (Pannonian Basin and South China Sea) [Tapponnier et al., 1982; Ratschbacher et al., 1991]. In contrast, extrusion in Timor appears to be early syn-collisional. Despite the small temporal and spatial scale, and comparatively early onset of extrusion in Timor, the similar geometries of faulting between these diverse orogens suggest that the underlying mechanism is similar [e.g., Yin and Taylor, 2011].

[60] We propose that collision in the vicinity of Timor Leste initiated when a narrow outlying Timor Plateau [e.g., Snyder et al., 1996a] arrived at the subduction trench $>5 \mathrm{Ma}$ [Duffy, 2013; Nguyen et al., 2013] and was underthrust (Figure 15a). The low density continental material resisted subduction and was duplexed and thickened into a nappe stack [Harris, 1991] (Figures 2b and 15b), which locally domed and stretched the fore arc over a core of buoyant continental material. Doming caused normal faulting in the upper plate (Figure 15b), which became increasingly coupled with the thickened plateau and locally accelerated to a velocity approaching that of the Australian continent [e.g., Nugroho et al., 2009]. This resulted in arc-parallel extension that was focused in the vicinity of the Marobo basin. Peri-collisional extension of the fore arc also occurred at the western (trailing) end of the underthrust plateau as documented by the late Miocene Ocussi volcanics [Harris, 1992]. Analagous magmatic events may include Paleogene magmatism in Tibet prior to initiation of slip on the Ailao Shan-Red River shear zone [Chung et al., 1997]. Oblique slip on normal faults drove the exhumation of deeper structural levels of east Timor, particularly the Ramelau Arch, east of the Marobo Graben. The Maliana graben (Figure 3) that lies west of the Marobo Graben and the Atambua graben immediately across the border in West Timor are probably also extensional features that overprint the edge of the thrust stack.

[61] Volcanism north of Timor ceased at around 2.4 Ma [Herrington et al., 2011] (Figure 15c). Continued convergence back-folded the domed fore-arc roof thrust [Harris, 1991] and began to thrust the thickened orogenic wedge northward over the fore arc along the Wetar Suture around 3.5Ma [Price and Audley-Charles, 1987] (Figures 2 and $15 \mathrm{c})$. Several papers have investigated the fate of the downgoing slab, which has been regarded as delaminating or in the process of rupturing [Sandiford, 2008; Spakman and Hall, 2010]. We cannot comment in this regard, except to say that the ocean crust either side of the Timor Plateau probably continued to subduct. The plateau crust, above which the fore arc was already being stretched, extruded perpendicular to shortening, into the free space created by coupling-related extension and by the subduction of adjoining oceanic crust.

[62] Syncollisional extrusion of the underthrust Timor Plateau and arc-parallel extension of the upper plate rapidly exhumed the Timor orogenic wedge including the Ramelau Arch, which we interpret as an extensional window, bounded by normal faults and similar in many respects to the Lautern Window of the Eastern Alps (Figure 14b). Like the Lautern Window, the highest topography in Timor is found in the Ramelau Window (Figure 3). Extrusion of accreted continental crust, and collapse of its margins, was responsible for the preservation of gently deformed synorogenic sediments that accumulated in extensional basins. Subduction locking [Keep and Haig, 2010] did not occur, and earthquakes indicate that thrusting still occurs along the basal décollement north of the Timor Trough (Figure 2). The extension associated with extrusion of Timor is therefore still fundamentally syn-collisional rather than post-collisional [cf. Charlton, 1997; Audley-Charles, 2011].

[63] Our model for collision in Timor suggests that collision propagated both east and west from Timor Leste. This is compatible with the irregular geometry of the Australian passive margin, indentation of the thrust front, and spread of continental contamination of the arc away from Wetar through time. An analagous situation is presently developing west of Timor, where the island of Sumba is being uplifted by subduction of the buoyant Scott Plateau and exhumed by extension [Fortuin et al., 1997; Fleury et al., 2009]. This study reinforces the practice of geologists who look to Sumba as a time for space analogy for Timor [e.g., AudleyCharles, 1985; 2004].

[64] DeMets et al. [2010] relative motion vectors are consistent with GPS campaign vectors in the Banda Arc [Nugroho et al., 2009] which suggests that GPS may reflect long-term trends. We therefore use the consistency between mapped deformation, modern seismicity, and GPS vector azimuths (Figure 13) to evaluate the timing and rates of extrusion. Wetar is strongly coupled to the Timor orogen, so although it lies in the arc, it is used as a proxy for the GPS velocity of Timor. Averaged across the $575 \mathrm{~km}$ between Savu and Wetar, Nugroho et al. 's [2009] 12 mm/yr differential global velocity between those locations (Figure 13) yields an extensional strain rate of $0.2 \mathrm{E}-07 / \mathrm{yr}$. This strain rate probably increases westward from Wetar, reaching rates of $\sim 0.7 \mathrm{E}-07 / \mathrm{yr}$ near the modern subduction-collision 

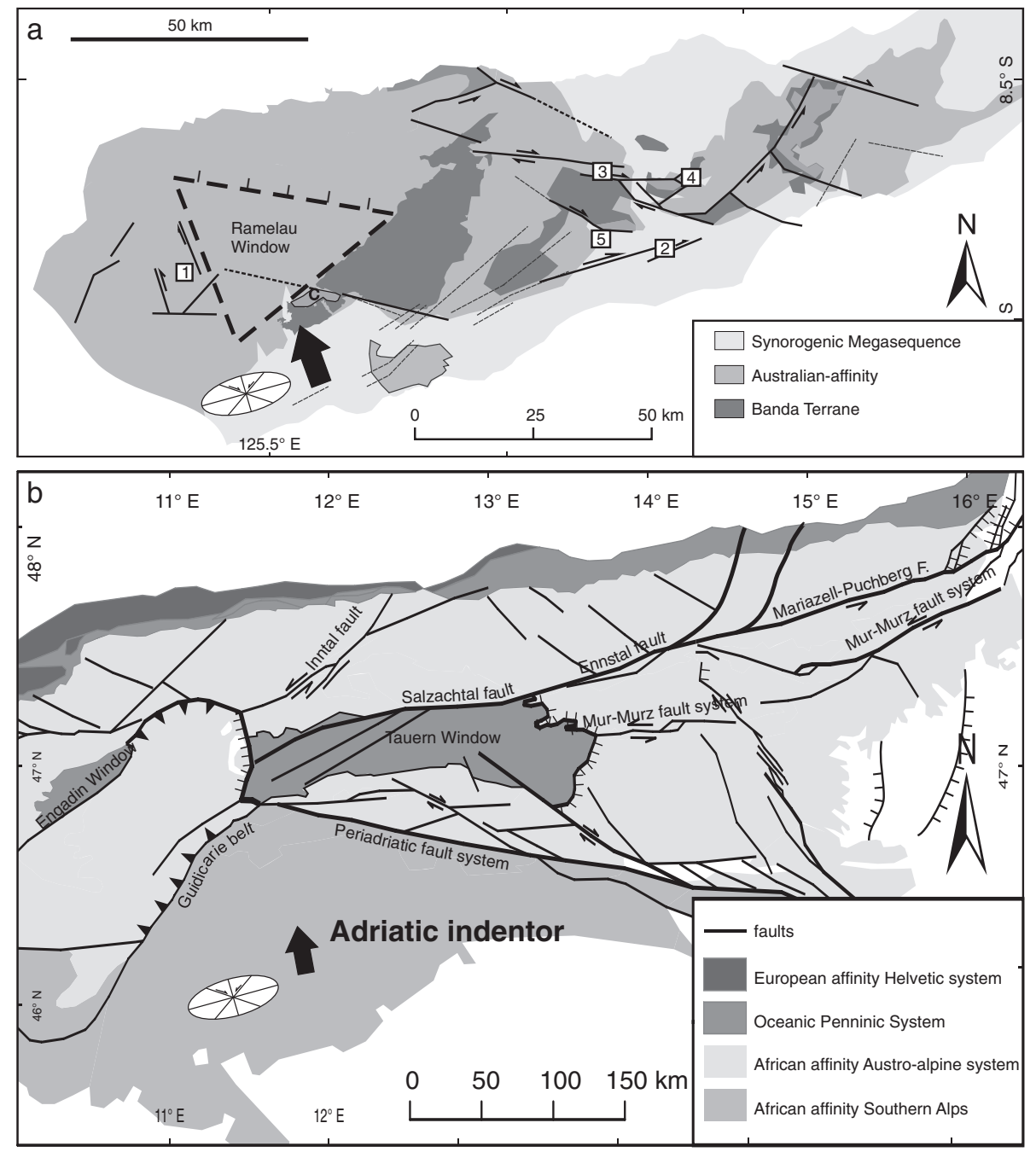

Figure 14. Regional transtension along conjugate strike slip faults. Shortening direction in both figures indicated by heavy black arrow. (a) Faulting in Timor. Note the orientation of faults relative to the telescope-like geometry of the coastline. Fine dotted lines are faults mapped by Audley-Charles [1968] along the south coast that seem compatible with the present study. (b) Comparitive generalized tectonic map of the European Alps, showing dismemberment and extrusion of the Eastern (Austroalpine) Alps associated with strike slip extrusion along structures similar to those observed in Timor. The Austroalpine rocks are being extruded eastward along non-Andersonian conjugate strike slip faults [Ratschbacher et al., 1991; Frisch et al., 1998].

transition (Figure 13) [Bock et al., 2003]. These modern GPS derived strain rates can account for about $11.5 \%$ (or $66 \mathrm{~km}$ ) of stretching over that distance during $5.5 \mathrm{Myr}$, which is the minimum lapsed time since the inception of orogen-parallel extension in the Marobo basin. Of this, we have shown that at least $20 \mathrm{~km}$ was localized in the NE extension domain of Timor Leste.

\section{Conclusions}

[65] Timor Leste is extending parallel to the Banda arc by general shear on non-Andersonian conjugate transtensional faults. We propose that the extension resulted from collision of an outlying plateau that arrived south of Wetar and was bounded by ocean crust to both west and east. The onset of extension was rapid and involved both the upper and lower plates. Doming of the fore arc above the thickened, buoyant, underplated continental plateau locally increased the coupling of the arc and caused arc-parallel extension in the upper plate, leading to the eruption of the Ocussi Volcanics. Continued shortening of the plateau caused extrusion toward the west and east margins, which were less constrained due to subduction of their oceanic crust. The extrusion episode is recorded by intersecting, oppositesense Riedel shears, such as the Lacluta and Mata Bia faults, that dip toward the major arc-parallel Laclo and Viqueque strike slip faults. The extrusion in Timor is similar to extrusion documented at much larger scales in the European Alps and Tibet. It is also consistent with analogue models of the transition from subduction to arc-continent collision [e.g., Boutelier et al., 2012] and with theoretical and analogue models of extrusion [Yin and Taylor, 2011].

[66] The obliquity of island arc-continent collisions, such as Taiwan and Timor, gives rise to the concept of space-time 

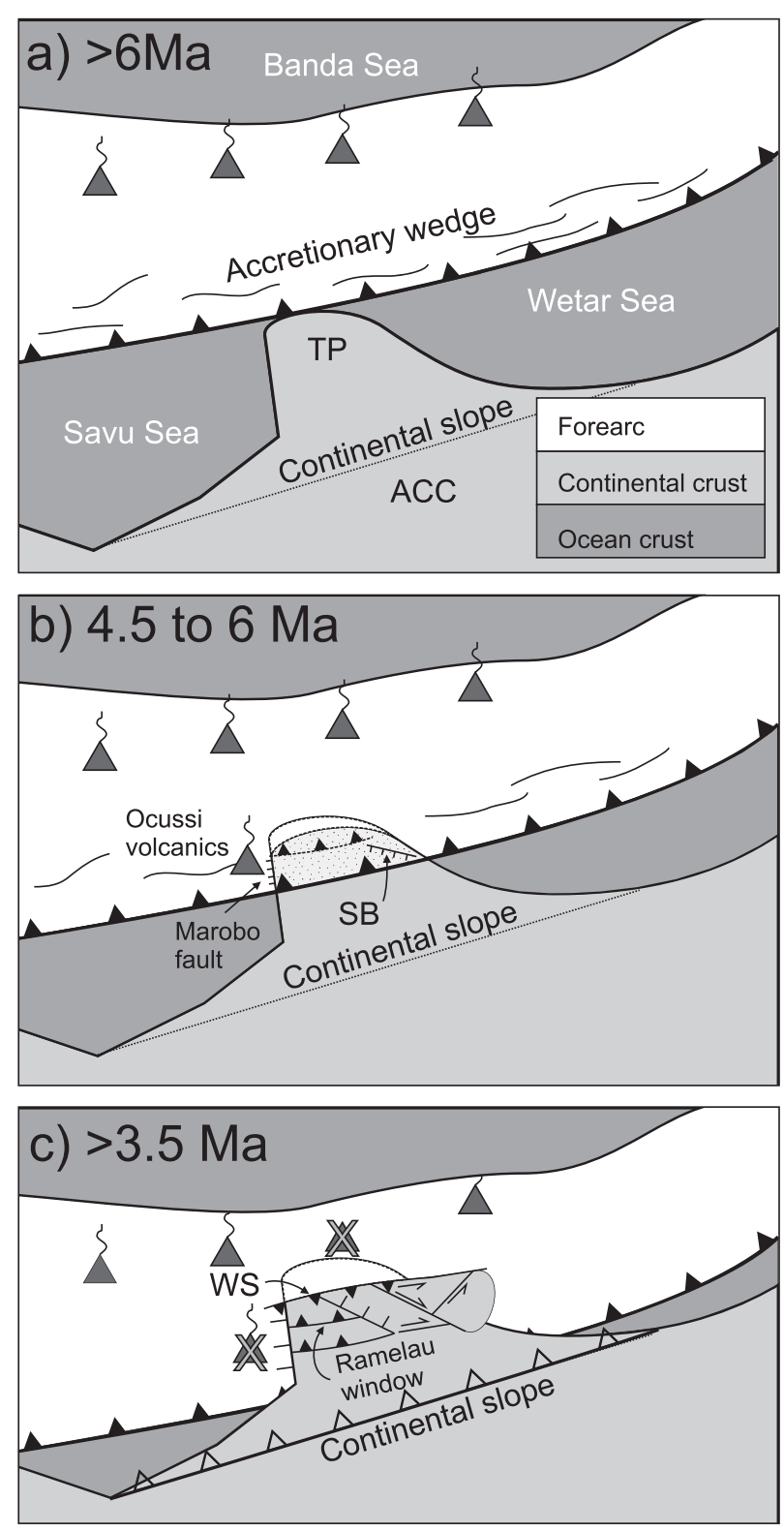

Figure 15. Schematic representation of the geodynamic development of Timor Leste. Smoking triangles are active volcanoes. ACC, Australian Continental crust. (a) The Timor Plateau arrives at the subduction trench, where it begins to be underplated. (b) The underplated Timor Plateau (stippled) is shortened by duplexing on southfacing thrusts. The plateau resists subduction and extension of the duplexed plateau and overthrust fore-arc is initiated along the Marobo fault as the ocean crust continue to subduct. The Ocussi volcanics are erupted on the ocean floor west of the Marobo graben. The uplifted fore arc begins shedding sediment into synorogenic grabens. (c) Volcanism on Wetar ceases. Uplift of the buoyant plateau and continued convergence lead to the thrusting of the duplexed plateau over the fore arc along the Wetar Suture that lies north of Timor Leste. Erosion and extension of the uplifted fore arc exposes the duplexed plateau in the Ramelau Arch (window). The indenting Timor Plateau extrudes eastward under the adjacent fore arc basement. equivalence [e.g., Suppe, 1984; Harris, 1991; Roosmawati and Harris, 2009], in which the history of development of older parts of the orogen is inferred by examining along strike analogues. This assumes a regular progression and may neglect short wavelength variability in the geometry of the colliding margin. The detailed pre-collisional crustal geometry of the lower plate (e.g., indentor presence and shape) exerts an important influence on the structural evolution of both upper and lower plate crusts during collision.

[67] Acknowledgments. Helpful reviews and editorial comments from Mike Taylor, Lothar Ratschbacher, and an anonymous reviewer greatly improved this manuscript. Bedding and fault kinematic data were plotted using StereoWin and FaultKinWin software by Rick Allmendinger. This work was supported by a Royal Society of New Zealand Marsden Research Council grant to Quigley (Fast-start grant M1137), a Tertiary Education Commission Top Achiever scholarship to Duffy, and U.S. National Science Foundation grants to Harris. We thank Norberta da Costa and her staff in the Secretariat for Energy and Natural Resources (SERN) in Dili for their continuing support for our research in Timor Leste. Jhony Suares, Lamberto Fernandes, Jhony Rheis, Andy Monteiro, Atino Varela, Lourenço Pedro, Cecilia, and Nabe all provided valuable field assistance and local knowledge. We thank the local administrators and community leaders for their hospitality and access to field areas. We thank Aaron Benincasa for his friendship and logistic support. We enjoyed discussions in the field with James Shulmeister, Mike Sandiford, Douwe Van Hinsbergen, Louise Moody, Richard Bakker, David Haig, and Myra Keep.

\section{References}

Audley-Charles, M. G. (1968), The Geology of Portugese Timor, Geol. Soc. of London, London, $75 \mathrm{pp}$

Audley-Charles, M. G. (1985), The Sumba enigma: Is Sumba a diapiric fore-arc nappe in process of formation?, Tectonophysics, 119(1-4), 435-449.

Audley-Charles, M. G. (2004), Ocean trench blocked and obliterated by Banda forearc collision with Australian proximal continental slope, Tectonophysics, 389(1-2), 65-79.

Audley-Charles, M. G. (2011), Tectonic post-collision processes in Timor, in The SE Asian Gateway: History and Tectonics of the Australia-Asia Collision, edited by R. Hall, M. A. Cottam, and M. E. J. Wilson, Spec. Publ. Geol. Soc. London, 355, 241-266.

Audley-Charles, M. G., D. J. Carter, A. J. Barber, M. S. Norvick, and S. Tjokrosapoetro (1979), Reinterpretation of the geology of Seram: Implications for the Banda Arcs and northern Australia, J. Geol. Soc., 136(5), 547-568.

Audley-Charles, M. G., P. D. Ballantyne, and R. Hall (1988), MesozoicCenozoic rift-drift sequence of Asian fragments from Gondwanaland, Tectonophysics, 155(1-4), 317-330.

Ave Lallemant, H. G., and L. R. Guth (1990), Role of extensional tectonics in exhumation of eclogites and blueschists in an oblique subduction setting: Northeastern Venezuela, Geology, 18(10), 950-953.

Barber, A. J., S. Tjokrosapoetro, and T. R. Charlton (1986), Mud volcanoes, shale diapirs, wrench faults and melanges in accretionary complexes, eastern Indonesia, Am. Assoc. Pet. Geol. Bull., 70(11), 1729-1741.

Benincasa, A., M. Keep, and D. W. Haig (2012), A restraining bend in a young collisional margin: Mount Mundo Perdido, East Timor, Aust. J. Earth Sci., 59(6), 859-876.

Berry, R. F. (1981), Petrology of the Hili Manu Lherzolite, East Timor, J. Geol. Soc. Aust., 28, 453-469.

Berry, R. F., and A. E. Grady (1981), Deformation and metamorphism of the Aileu Formation, north coast, East Timor and its tectonic significance, $J$. Struct. Geol., 3(2), 143-167.

Berry, R. F., and I. McDougall (1986), Interpretation of ${ }^{40} \mathrm{Ar} /{ }^{39} \mathrm{Ar}$ and $\mathrm{K} / \mathrm{Ar}$ dating evidence from the Aileu Formation, East Timor, Indonesia, Chem. Geol., 59, 43-58.

Bock, Y., L. Prawirodirdjo, J. F. Genrich, C. W. Stevens, R. McCaffrey, C. Subarya, S. S. O. Puntodewo, and E. Calais (2003), Crustal motion in Indonesia from Global Positioning System measurements, J. Geophys. Res., 108(8), 2367, doi:10.1029/2001JB000324, 2003.

Boutelier, D., O. Oncken, and A. Cruden (2012), Fore-arc deformation at the transition between collision and subduction: Insights from 3-D thermomechanical laboratory experiments, Tectonics, $31(2)$.

Bowin, C., G. M. Purdy, C. Johnston, G. Shor, L. Lawver, M. S. Hartono, and P. Jezek (1980), Arc-continent collision in the Banda Sea region, Am. Assoc. Pet. Geol. Bull., 64, 868-918.

Breen, N. A., E. A. Silver, and D. M. Hussong (1986), Structural styles of an accretionary wedge south of the island of Sumba, Indonesia, revealed by 
Sea Marc II side scan sonar, Geol. Soc. Am. Bull., 97, 1250-1261, doi:10.1130/0016-7606.

Breen, N. A., E. A. Silver, and S. Roof (1989), The Wetar back arc thrust belt, eastern Indonesia: The effect of accretion against an irregularly shaped arc, Tectonics, 8(1), 85-98.

Brouwer, H. A. (1942), Summary of the geological results of the expeditions, Geological Expeditions to the Lesser Sunda Islands, 4, 345-402.

Brown, D., and C. Y. Huang (2009), An introduction to the Tectonophysics special issue on arc-continent collision processes, Tectonophysics, 479(1-2), 1-3, doi:10.1016/j.tecto.2009.11.008.

Calassou, S., C. Larroque, and J. Malavieille (1993), Transfer zones of deformation in thrust wedges: An experimental study, Tectonophysics, 221(3-4), 325-344.

Carter, D. J., M. G. Audley-Charles, and A. J. Barber (1976), Stratigraphical analysis of island arc-continental margin collision in eastern Indonesia, $J$. Geol. Soc. London, 132, 179-198.

Charlton, T. R. (1989), Stratigraphic correlation across an arc-continent collision zone: Timor and the Australian Northwest Shelf, Aust. J. Earth Sci., 36(2), 263-274.

Charlton, T. R. (1991), Postcollision extension in arc-continent collision zones, eastern Indonesia, Geology, 19(1), 28-31.

Charlton, T. R. (1997), Backthrusting on the BIRPS deep seismic reflection profiles, Banda Arc, Indonesia, a response to changing slab inclination?, $J$. Geol. Soc. London, 154(2), 169-172.

Charlton, T. R. (2002), The petroleum potential of East Timor, APPEA J., 42, 351-369.

Charlton, T. R., and Suharsono (1990), Mesozoic-Tertiary stratigraphy of the Kolbano area, Southern West Timor, Bull. Geol. Res. Dev. Cent., 14, 38-58.

Charlton, T. R., and D. Wall (1994), New biostratigraphic results from the Kolbano area, southern West Timor: Implications for the Mesozoic-Tertiary stratigraphy of Timor, J. Southeast Asian Earth Sci., 9(1-2), 113-122.

Charlton, T. R., A. J. Barber, and S. T. Barkham (1991), The structural evolution of the Timor collision complex, eastern Indonesia, J. Struct. Geol., 13(5), 489-500.

Chung, S.-L., T.-Y. Lee, C.-H. Lo, P.-L. Wang, C.-Y. Chen, N. T. Yem, T. T. Hoa, and W. Genyao (1997), Intraplate extension prior to continental extrusion along the Ailao Shan-Red River shear zone, Geology, 25(4), 311-314, doi:10.1130/0091-7613(1997)025<0311:ieptce $>2.3 . c 0 ; 2$.

Clift, P. D., J. F. Dewey, A. E. Draut, D. M. Chew, M. Mange, and P. D. Ryan (2004), Rapid tectonic exhumation, detachment faulting and orogenic collapse in the Caledonides of western Ireland, Tectonophysics, 384(1-4), 91-113, doi:10.1016/j.tecto.2004.03.009.

Cloos, M. (1993), Lithospheric buoyancy and collisional orogenesis: Subduction of oceanic plateaus, continental margins, island arcs, spreading ridges, and seamounts, Geol. Soc. Am. Bull., 105(6), 715-737, doi:10.1130/0016-7606(1993)105<0715:1bacos > 2.3.co;2.

Crostella, A., and D. E. Powell (1975), Geology and Hydrocarbon Prospects of the Timor area, Paper Presented at 4th Annual Convention of the Indonesian Petroleum Association, p. 1-17, BOC of Australia Limited, Jakarta, Indonesia.

Davis, D., J. Suppe, and F. A. Dahlen (1983), Mechanics of fold-and-thrust belts and accretionary wedges, J. Geophys. Res., 88(B2), 1153-1172.

DeMets, C., R. G. Gordon, and D. F. Argus (2010), Geologically current plate motions, Geophys. J. Int., 181(1), 1-80.

de Waard, D. (1956), Geology of a N-S section across western Timor, Indonesian, J. Nat. Sci., 112, 101-114.

Dewey, J. F. (2005), Orogeny can be very short, Proc. Natl. Acad. Sci. U. S. A., 102(43), 15286-15293, doi:10.1073/pnas.0505516102.

Dominguez, S., S. E. Lallemand, and J. Malavieille (1998), Upper plate deformation associated with seamount subduction, Tectonophysics, 293, 207-224.

Duffy, B. (2013), The structural and geomorphic development of active collisional orogens, from single earthquake to million year timescales, Timor Leste and New Zealand, PhD thesis, 238 pp, Univ. of Canterbury, Christchurch, New Zealand.

Duffy, B., M. C. Quigley, D. Barrell, R. Van Dissen, T. Stahl, S. Leprince, C. McInnes, and E. Bilderback (2013), Fault kinematics and surface deformation across a releasing bend during the $2010 \mathrm{M}_{\mathrm{W}} 7.1$ Darfield, New Zealand, earthquake revealed by differential LiDAR and cadastral surveying, Geol. Soc. Am. Bull., 125(3-4), 420-431, doi:10.1130/B30753.1.

Earle, M. M. (1980), A Study of Boi and Mollo, two metamorphic massifs on Timor, Eastern Indonesia, $\mathrm{PhD}$ thesis, 240 pp, Univ. of London, London.

Ely, K. S. (2009), Geochronology of Timor-Leste and seismo-tectonics of the southern Banda Arc, $\mathrm{PhD}$ thesis, 282 pp, Univ. of Melbourne, Melbourne.

Fleury, J.-M., M. Pubellier, and M. de Urreiztieta (2009), Structural expression of forearc crust uplift due to subducting asperity, Lithos, 113(1-2), 318-330.

Fortuin, A. R., W. van der Werff, and H. Wensink (1997), Neogene basin history and paleomagnetism of a rifted and inverted forearc region, onand offshore Sumba, Eastern Indonesia, J. Asian Earth Sci., 15, 61-88.

Frisch, W., J. Kuhlemann, I. Dunkl, and A. Brügel (1998), Palinspastic reconstruction and topographic evolution of the Eastern Alps during late Tertiary tectonic extrusion, Tectonophysics, 297(1-4), 1-15.
Ganas, A., S. Pavlides, and V. Karastathis (2005), DEM-based morphometry of range-front escarpments in Attica, central Greece, and its relation to fault slip rates, Geomorphology, 65(3-4), 301-319.

Genrich, J. F., Y. Bock, R. McCaffrey, E. Calais, C. W. Stevens, and C. Subarya (1996), Accretion of the southern Banda arc to the Australian plate margin determined by Global Positioning System measurements, Tectonics, 15(2), 288-295.

Gorney, D., A. Escalona, P. Mann, M. B. Magnani, and B. S. Group (2007), Chronology of Cenozoic tectonic events in western Venezuela and the Leeward Antilles based on integration of offshore seismic reflection data and on-land geology, AAPG Bull., 91(5), 653-684, doi:10.1306/11280606002.

Grady, A. E., and R. F. Berry (1977), Some Palaeozoic-Mesozoic stratigraphic-structural relationships in East Timor and their significance to the tectonics of Timor, J. Geol. Soc. Aust., 24, 203-214.

Haig, D. W. (2012), Palaeobathymetric gradients across Timor during 5.73.3Ma (latest Miocene-Pliocene) and implications for collision uplift, Palaeogeogr. Palaeoclimatol. Palaeoecol., 331-332, 50-59.

Haig, D. W., and E. McCartain (2007), Carbonate pelagites in the postGondwana succession (Cretaceous-Neogene) of East Timor, Aust. J. Earth Sci., 54(6), 875-897.

Haig, D. W., E. McCartain, L. Barber, and J. Backhouse (2007), Triassic-lower Jurassic foraminiferal indices for bahaman-type carbonate-bank limestones, Cablac Mountain, East Timor, J. Forami. Res., 37(3), 248-264.

Haig, D. W., E. McCartain, M. Keep, and L. Barber (2008), Re-evaluation of the Cablac Limestone at its type area, East Timor: Revision of the Miocene stratigraphy of Timor, J. Asian Earth Sci., 33(5-6), 366-378.

Hamilton, W. (1979), Tectonics of the Indonesian region, U.S. Geol. Surv., Prof. Pap., 1078, 345.

Harris, R. A. (1991), Temporal distribution of strain in the active Banda orogen: A reconciliation of rival hypotheses, J. Southeast Asian Earth Sci., 6(3-4), 373-386.

Harris, R. A. (1992), Peri-collisional extension and the formation of Oman-type ophiolites in the Banda arc and Brooks Range, in Ophiolites and their modern oceanic analogues, edited by L. M. Parson, B. J. Murton and P. Browning Spec. Publ. Geol. Soc. London, 60, 301-325.

Harris, R. A. (2006), Rise and fall of the Eastern Great Indonesian arc recorded by the assembly, dispersion and accretion of the Banda Terrane, Timor, Gondwana Res., 10(3-4), 207-231.

Harris, R. A. (2011), The nature of the Banda Arc-Continent collision in the Timor Region, in Arc-Continent Collision, edited by D. Brown and P. D. Ryan, pp. 163-211, Springer, Berlin.

Harris, R. A., and S. Wu (1992), Comment on "Post-collisional extension in arc-continent collision zones, eastern Indonesia", Geology, 20(1), 92-93, doi:10.1130/0091-7613(1992)020<0092:CAROPE > 2.3.CO;2.

Harris, R. A., R. K. Sawyer, and M. G. Audley-Charles (1998), Collisional melange development: Geologic associations of active melange-forming processes with exhumed melange facies in the western Banda orogen, Indonesia, Tectonics, 17(3), 458-479.

Harris, R. A., J. Kaiser, A. Hurford, and A. Carter (2000), Thermal history of Australian passive margin cover sequences accreted to Timor during Late Neogene arc-continent collision, Indonesia, J. Asian Earth Sci., 18(1), 47-69.

Harris, R. A., M. W. Vorkink, C. Prasetyadi, E. Zobell, N. Roosmawati, and M. Apthorpe (2009), Transition from subduction to arc-continent collision: Geologic and neotectonic evolution of Savu Island, Indonesia, Geosphere, 5, 152-171.

Herrington, R. J., P. M. Scotney, S. Roberts, A. J. Boyce, and D. Harrison (2011), Temporal association of arc-continent collision, progressive magma contamination in arc volcanism and formation of gold-rich massive sulphide deposits on Wetar Island (Banda arc), Gondwana Res., 19(3), 583-593, doi:10.1016/j.gr.2010.10.011.

Karig, D. E., A. J. Barber, T. R. Charlton, S. Klemperer, and D. M. Hussong (1987), Nature and distribution of deformation across the Banda ArcAustralian collision zone at Timor, Geol. Soc. Am. Bull., 98(1), 18-32.

Keep, M., and D. W. Haig (2010), Deformation and exhumation in Timor: Distinct stages of a young orogeny, Tectonophysics, 483(1-2), 93-111, doi:10.1016/j.tecto.2009.11.018.

Keep, M., L. Barber, and D. W. Haig (2009), Deformation of the Cablac Mountain Range, East Timor: An overthrust stack derived from an Australian continental terrace, J. Asian Earth Sci., 35(2), 150-166, doi:10.1016/j.jseaes.2009.02.001.

Kenyon, C. S. (1974), Stratigraphy and sedimentology of the Late Miocene to Quaternary deposits in Timor., PhD thesis, Univ. of London, London. Lawless, J. V., B. G. Lovelock, and G. N. Ussher (2005), Geothermal potential of East Timor, paper presented at World Geothermal Congress 2005, Antalya, Turkey, 24-29 April 2005.

Lister, G., and M. Forster (2009), Tectonic mode switches and the nature of orogenesis, Lithos, 113(1-2), 274-291. doi:10.1016/j.lithos.2008.10.024 


\section{DUFFY ET AL.: ARC-PARALLEL EXTRUSION OF TIMOR}

Masson, D. G., J. Milsom, A. J. Barber, N. Sikumbang, and B. Dwiyanto (1991), Recent tectonics around the island of Timor, eastern Indonesia, Mar. Pet. Geol., 8(1), 35-49.

McCaffrey, R. (1988), Active tectonics of the Eastern Sunda and Banda Arcs, J. Geophys. Res., 93(B12), 15163-15182.

McCaffrey, R. (1989), Seismological constraints and speculations on Banda Arc Tectonics, Neth. J. Sea Res., 24(2/3), 141-152.

McCaffrey, R. (1996), Estimates of modern arc-parallel strain rates in fore arcs, Geology, 24(1), 27-30, doi:10.1130/0091-7613(1996)024<0027: eomaps $>2.3 . \mathrm{co} ; 2$.

Metcalfe, I. (1996), Pre-Cretaceous evolution of SE Asian terranes, in Tectonic Evolution of Southeast Asia, edited by R. Hall, and D. J. Blundell, Spec. Publ. Geol. Soc. London, 106, 97-122.

Milsom, J., and M. G. Audley-Charles (1986), Pos-collision isostatic readjustment in the southern Banda Arc, in Collision Tectonics, edited by M. P. Coward, and A. C. Ries, Spec. Publ. Geol. Soc. London, 19 , 353-364.

Molnar, P., and P. Tapponnier (1975), Cenozoic tectonics of Asia: Effects of a continental collision, Science, 189(4201), 419-426.

Mourgues, R., and P. R. Cobbold (2006), Thrust wedges and fluid overpressures: Sandbox models involving pore fluids, J. Geophys. Res., 111, B05404, doi:10.1029/2004jb003441.

Nguyen, N., B. Duffy, J. Shulmeister, and M. C. Quigley (2013), Rapid Pliocene uplift of Timor, Geology, 41(2), 179-182, doi:10.1130/G33420.1.

Nugroho, H., R. A. Harris, A. W. Lestariya, and B. Maruf (2009), Plate boundary reorganization in the active Banda Arc-Continent collision: Insights from new GPS measurements, Tectonophysics, 479(1-2), 52-65.

Planert, L., H. Kopp, E. Lueschen, C. Mueller, E. R. Flueh, A. Shulgin, Y. Djajadihardja, and A. Krabbenhoeft (2010), Lower plate structure and upper plate deformational segmentation at the Sunda-Banda arc transition, Indonesia, J. Geophys. Res., 115, B08107, doi:10.1029/2009jb006713.

Price, N. J., and M. G. Audley-Charles (1987), Tectonic collision processes after plate rupture, Tectonophysics, 140(2-4), 121-129.

Pubellier, M., and P. R. Cobbold (1996), Analogue models for the transpressional docking of volcanic arcs in the Western Pacific, Tectonophysics, 253(1-2), 33-52.

Quigley, M. C., B. Duffy, J. Woodhead, J. Hellstrom, L. Moody, T. Horton J. Suares, and L. Fernandes (2012), U/Pb dating of a terminal Pliocene coral from the Indonesian Seaway, Mar. Geol., 311-314, 57-62.

Ratschbacher, L., W. Frisch, H. G. Linzer, and O. Merle (1991), Lateral extrusion in the eastern Alps, Part 2: Structural analysis, Tectonics, 10(2), 257-271.

Richardson, A. N., and D. J. Blundell (1996), Continental collision in the Banda Arc, in Tectonic Evolution of Southeast Asia, edited by R. Hall, and D. J. Blundell, Spec. Publ. Geol. Soc. London, 106, 47-60.

Ring, U., J. Glodny, S. Thomson, and T. Will (2010), The Hellenic subduction system: High-pressure metamorphism, exhumation, normal faulting and large-scale extension, Annu. Rev. Earth Planet. Sci., 38, 45-76, doi:10.1146/annurev.earth.050708.170910.

Roosmawati, N., and R. A. Harris (2009), Surface uplift history of the incipient Banda arc-continent collision: Geology and synorogenic foraminifera of Rote and Savu Islands, Indonesia, Tectonophysics, 479(1-2), 95-110, doi:10.1016/j.tecto.2009.04.009.

Sandiford, M. (2008), Seismic moment release during slab rupture beneath the Banda Sea, Geophys. J. Int., 174(2), 659-671.

Sawyer, R. K., K. Sani, and S. Brown (1993), The stratigraphy and sedimentology of West Timor, Indonesia, in Proceedings of the Indonesian Petroleum Association, Twenty Second Annual Convention, pp. 533-574.
Shulgin, A., H. Kopp, C. Mueller, E. Lueschen, L. Planert, M. Engels, E. R. Flueh, A. Krabbenhoeft, and Y. Djajadihardja (2009), SundaBanda arc transition: Incipient continent-island arc collision (northwest Australia), Geophys. Res. Lett., 36, L10304, doi:10.1029/ $2009 \mathrm{gl037533.}$

Silver, E. A., D. Reed, R. McCaffrey, and Y. Joyodiwiryo (1983), Back arc thrusting in the eastern Sunda arc, Indonesia: A consequence of arccontinent collision, J. Geophys. Res., 88(B9), 7429-7448.

Snyder, D. B., J. Milsom, and H. Prasetyo (1996a), Geophysical evidence for local indentor tectonics in the Banda Arc east of Timor, in Tectonic Evolution of Southeast Asia, edited by D. J. Blundell, and R. Hall, Spec. Publ. Geol. Soc. London, 106, 61-73.

Snyder, D. B., H. Prasetyo, D. J. Blundell, C. J. Pigram, A. J. Barber, A. Richardson, and S. Tjokosaproetro (1996b), A dual doubly vergent orogen in the Banda Arc continent-arc collision zone as observed on deep seismic reflection profiles, Tectonics, 15(1), 34-53.

Spakman, W., and R. Hall (2010), Surface deformation and slab-mantle interaction during Banda arc subduction rollback, Nat. Geosci., 3, 562-566. doi:10.1038/NGEO917.

Standley, C. E., and R. A. Harris (2009), Tectonic evolution of forearc nappes of the active Banda arc-continent collision: Origin, Age, Metamorphic History and Structure of the Lolotoi Complex, East Timor, Tectonophysics, doi:10.1016/j.tecto.2009.01.034.

Suppe, J. (1984), Kinematics of arc-continental collision, flipping of subduction, and back-arc spreading near Taiwan, Mem. Geol. Soc. China (Taiwan), 6, 21-33

Tapponnier, P., G. Peltzer, A. Y. Le Dain, R. Armijo, and P. Cobbold (1982), Propagating extrusion tectonics in Asia: New insights from simple experiments with plasticine, Geology, 10(12), 611-616, doi:10.1130/ 0091-7613(1982) $10<611$ :petian > 2.0.co;2.

Taylor, M., A. Yin, F. J. Ryerson, P. Kapp, and L. Ding (2003), Conjugate strike-slip faulting along the Bangong-Nujiang suture zone accommodates coeval east-west extension and north-south shortening in the interior of the Tibetan Plateau, Tectonics, 22(4), 1044

Teng, L. S., C. T. Lee, Y. B. Tsai, and L. Y. Hsiao (2000), Slab breakoff as a mechanism for flipping of subduction polarity in Taiwan, Geology, 28(2), $155-158$

Tjia, H. D. (1983), Earthquake stress directions in the Indonesian Archipelago, in Geodynamics of the Western Pacific-Indonesian Region, Geodyn. Ser., Vol. 11, edited by T. W. C. Hilde, and S. Uyeda, pp. 413-422, AGU, Washington, D.C.

van der Werff, W. (1995), Cenozoic evolution of the Savu Basin, Indonesia: Forearc basin response to arc-continent collision, Mar. Pet. Geol., 12(3) 247-262.

Von Der Borch, C. C. (1979), Continent-Island arc collision in the Banda Arc, Tectonophysics, 54(3-4), 169-193.

Walker, R. T., E. Molor, M. Fox, and A. Bayasgalan (2008), Active tectonics of an apparently aseismic region: Distributed active strike-slip faulting in the Hangay Mountains of central Mongolia, Geophys. J. Int., 174(3), $1121-1137$.

Wheller, G. E., R. Varne, J. D. Foden, and M. J. Abbott (1987) Geochemistry of quaternary volcanism in the Sunda-Banda arc, Indonesia, and three-component genesis of island-arc basaltic magmas, J. Volcanol. Geotherm. Res., 32(1-3), 137-160.

Yin, A., and M. H. Taylor (2011), Mechanics of V-shaped conjugate strike-slip faults and the corresponding continuum mode of continental deformation, Geol. Soc. Am. Bull., 123(9-10), 1798-1821, doi:10.1130/b30159.1. 